\title{
Hydrogeochemical characterization of reservoir waters undergoing salinization processes in Northeastern Brazil
}

\section{Caracterização hidrogeoquímica da água de reservatórios em processo de salinização no Nordeste do Brasil}

José do Patrocinio Hora Alves ${ }^{1}$ (D), Maria Hortência Rodrigues Lima ${ }^{1}$ (D) , Josefa Raimunda Dória ${ }^{1}$ (D) , Igor Santos Silva ${ }^{1}$ \& Adnivia Santos Costa Monteiro ${ }^{1}$ (D)

${ }^{1}$ Universidade Federal de Sergipe, São Cristóvão, SE, Brasil

E-mails: jphalves@uol.com.br (JPHA), hortenciamaria21@hotmail.com (MHRL), mundinhadori@hotmail.com (JRD), santos.igor@hotmail.com (ISS),adniviacosta@gmail.com (ASCM)

\begin{abstract}
The geochemical processes that potentially control the chemical characteristics of the waters of three reservoirs located in the state of Sergipe, Northeastern Brazil, were evaluated using the Gibbs diagram, correlation analysis, ionic ratios and geochemical modeling. The results of the reverse geochemical modeling applied between two water samples from each reservoir were in agreement with the observations of the correlation analysis and ionic ratios, which indicated sea salt dissolution, silicate weathering and, to a lesser extent, carbonate dissolution, as the main geochemical processes responsible for the chemical characteristics of the waters of the three reservoirs, also confirming the importance of ion exchange for the Macela and Ribeirópolis reservoirs. These findings therefore suggest that the growing salinization process of the reservoirs is mainly controlled by water-rock interactions and may also be influenced by contributions from evaporation and anthropogenic inputs.
\end{abstract}

Keywords: Multivariate analysis; Hydrogeochemistry; Water-rock interactions; Geochemical modeling; PHREEQC.

\section{RESUMO}

Os processos geoquímicos que potencialmente controlam as características químicas das águas de três reservatórios, situados no estado de Sergipe, Nordeste do Brasil, foram avaliados usando o diagrama de Gibbs, análise de correlação, razões iônicas e modelagem geoquímica. Os resultados da modelagem geoquímica inversa, aplicada entre duas amostras de água de cada reservatório, foram concordantes com as observações da análise de correlação e razões iônicas, que indicaram a dissolução do sal marinho, o intemperismo dos silicatos e em menor proporção a dissolução dos carbonatos, como os principais processos geoquímicos responsáveis pelas características químicas das águas dos três reservatórios, inclusive confirmaram a importância da troca iônica para os reservatórios Macela e Ribeirópolis. Os resultados sugerem, portanto, que o crescente processo de salinização dos reservatórios é controlado principalmente pela interação água - rocha, podendo ter também contribuição da evaporação e de aportes antropogênicos.

Palavras-chave: Análise multivariada; Hidrogeoquímica; Interações água-rocha; Modelagem geoquímica; PRHEEQC. 


\section{INTRODUCTION}

Freshwater, despite being essential for human well-being and for many natural systems, is unevenly distributed worldwide. Surface water storage in reservoirs is the most applied strategy to combat this fact, resulting in a considerable increase in the construction of small dams in the last decades (Carpenter et al., 2010).

Salinization may affect freshwater systems, especially in arid and semi-arid regions, and represents a significant risk to freshwater systems, with the potential to render water unsuitable for human consumption and irrigation and impact aquatic ecosystem health (Peck \& Hatton, 2003; Nielsen et al., 2003; Merchán et al., 2015). High evaporation and the return of irrigation flow are noted as some of the main processes involved in water salinization (Koh et al., 2007; Johansson et al., 2009; Abdel Wahed et al., 2014, 2015; Guo et al., 2018; Jia et al., 2020). Evaporation is a natural process and exceeds precipitation in many arid and semiarid regions, leading to increased ion concentrations in the water. While irrigation is an anthropogenic activity, it can accelerate the salinization process by increasing the weathering of surrounding material around the irrigated area. According to Lerman (2009) the greatest impacts on saline lake, in the last centuries, have occurred during agricultural expansion and mineral extraction. Droughts can also significantly impact salinization processes. For example, the effects of severe droughts between 1997 and 2009 in southwest Australia have already overcome previous problems related to the impact of agricultural practices. During a drought, the decline in water quantity results from the reduction of fresh rainfall input, increasing the lake's salinity. (Elsdon et al., 2009; Tweed et al., 2011).

Water salinization is a recurring problem in Northeastern Brazil, as the region's climatic conditions contribute significantly to the salinization processes. The literature (Santos et al., 2000; Souza Filho \& Campos, 2002; Meireles et al., 2007; Palácio et al., 2011; Fontes et al., 2015) has highlighted the following as potential factors for surface water salinization: (i) atmospheric deposition of marine aerosol, (ii) high salt concentration surface water influx; (iii) excessive evaporation rates (about $2000 \mathrm{~mm}$ /year), (iv) aquifers with high saline concentration that can reach surface waters and (v) no accumulated reservoir water renewal for long periods of time.

Santos et al. (2000) evaluated reservoirs located in the southwest of Bahia, the relationship between the water retention time and the age of the reservoir with salinization. They observed that in reservoirs with low accumulated water demand (irregular demand), the salinization increased with the age of the reservoir. While in reservoirs with regular demand, salinization increased with water retention time, regardless of the age of the reservoir.

A variety of geochemical processes control chemical surface water characteristics, including type of rain, degree of evaporation and rock weathering, with the latter considered the main process that gives rise to the ionic composition of surface waters. Evaporites, carbonates and silicates exhibit high solubility and are present in greater amounts in rocks, due to this, the most important ions for the chemical water composition are $\mathrm{Na}^{+}, \mathrm{K}^{+}$, $\mathrm{Ca}^{2+}, \mathrm{Mg}^{2+}, \mathrm{HCO}^{3-}, \mathrm{SO}_{4}{ }^{2-}$ and $\mathrm{Cl}^{-}$(Kumarasamy et al., 2014; Jiang et al., 2015; Abdel Wahed et al., 2015).
Hydrogeochemical studies allow for assessments on the associations between the chemical water composition and waterrock interactions and mineral dissolution, and the identification of potential relationships between these processes and hydrogeological, lithological, and anthropogenic activities (Subramani et al., 2010; Lin et al., 2012; Jiang et al., 2015). The most applied approaches for geochemical evaluations from hydrochemistry data are the Gibbs diagram, correlation analyses, ionic ratios, and geochemical modeling (Han et al., 2014; Karroum et al., 2017; Singh et al., 2017). Gibbs diagrams summarize the chemical evolution of surface waters and allows for the identification of mechanisms that control chemical water characteristics, such as atmospheric precipitation, water-rock interactions (weathering) and evaporation (Gibbs, 1970). By calculating the correlations and ratios between the different ions, it is possible to obtain valuable information concerning the geochemical processes that gave rise to the chemical water characteristics. Reverse geochemical modeling simulates mass transfers caused by water-rock interaction processes and, thus, provides evidence for variations in the chemical composition of waters from two different samples (Xing et al., 2013; Liu et al., 2020a).

Hydrogeochemical studies, mainly in Brazil, have focused on groundwater. Therefore, this study is noteworthy, as it deals with the hydrogeochemistry of reservoirs located in the state of Sergipe, Northeastern Brazil. This study evaluates three reservoirs in different salinities, but in all of them, weathering is the main process that gives rise to the ionic composition of its waters. The Gibbs diagram, correlation analysis and ionic ratios were used to identify the main hydrogeochemical processes related to the reservoirs water salinization. The study also demonstrates that it is possible to perform reverse modeling using two water samples from the same reservoir, but with different ionic compositions.

\section{MATERIAL AND METHODS}

\section{Study area}

The three studied reservoirs, Jacarecica I, Macela and Ribeirópolis, are located in the Sergipe River hydrographic basin (Figure 1). The Sergipe River basin is the most important hydrographic basin in the state, occupying a total area of $3,753.8$ $\mathrm{km}^{2}$, with 3,693.8 $\mathrm{km}^{2}$ located in Sergipe territory and the rest in the state of Bahia. The hydrographic basin area comprises a total of twenty-six municipalities, with a population of 933,625 inhabitants, of which 840,325 are located in the urban area and 93,300 , in the rural area. The main land uses and occupation in the basin area are urban soil, native vegetation, agricultural sugar cane and maize cultivation and pastures (Alves et al., 2018).

The Jacarecica I reservoir is located in the city of Itabaiana, built between 1985 and 1987, by the Sergipe Water Development and Irrigation Company (COHIDRO), which is also responsible for its administration. It is formed by the Jacarecica River dam, and displays an accumulation capacity of 4,700,000 $\mathrm{m}^{3}$, occupying $221 \mathrm{~km}^{2}$, with a main dam length of $420 \mathrm{~m}$ and maximum height of $20 \mathrm{~m}$. The reservoir was built with the main objective 


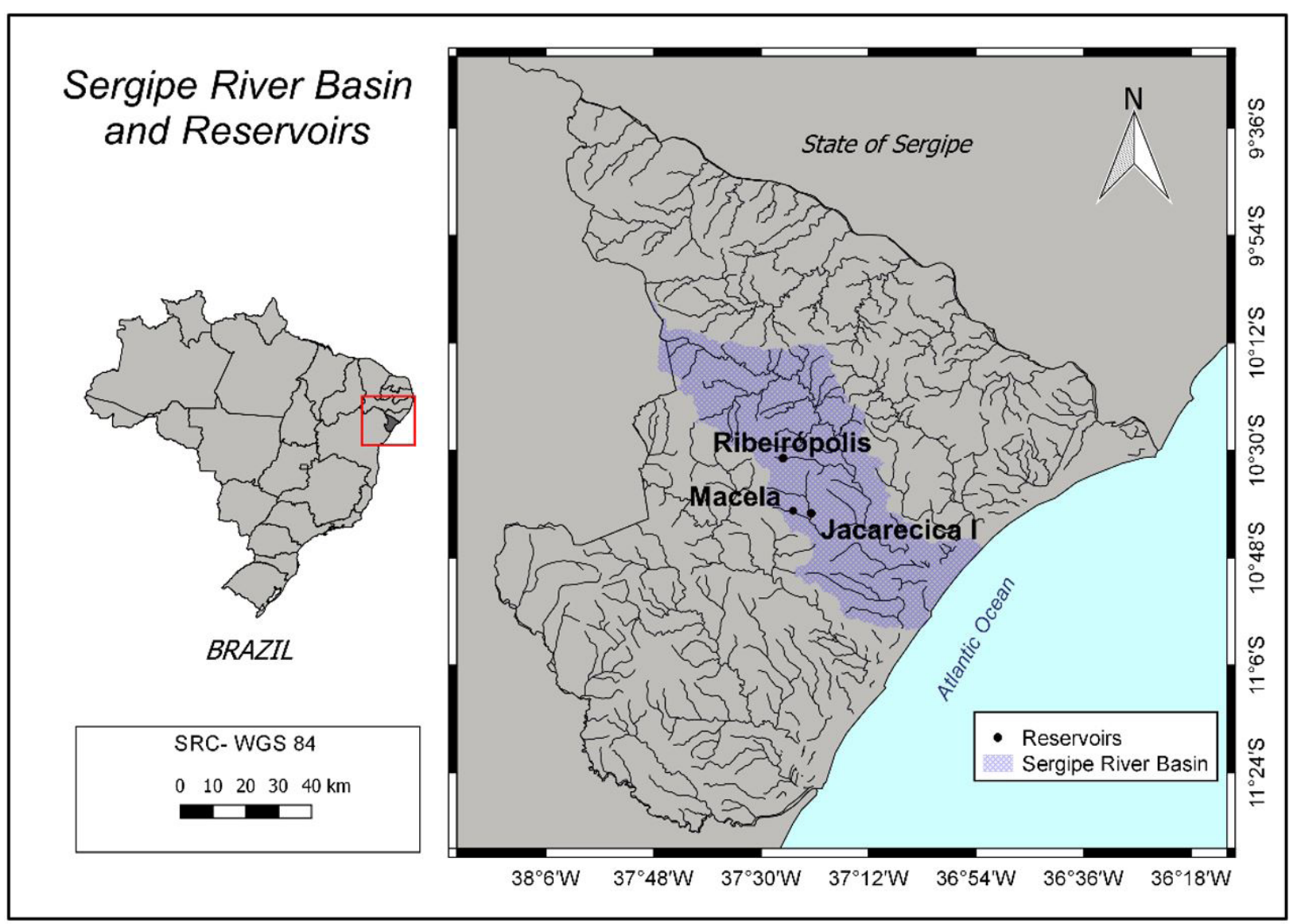

Figure 1. Study area indication and evaluated reservoir locations.

of supplying water to the irrigated Jacarecica I perimeter. The irrigated perimeter area is of $252 \mathrm{ha}$, with 2.0 ha plots occupied, predominantly, by family farmers, totaling approximately 150 families. The predominant crops are sweet potato, followed by vegetable crops. Regarding trophic status, the reservoir displays oligotrophic to eutrophic characteristics (Garcia et al., 2012).

The Macela reservoir, also located in the city of Itabaiana, was built between 1953 and 1957 by the National Department of Works Against Drought (DNOCS). It is formed by the Fuzil stream dam, with an accumulation capacity of $2,710,000 \mathrm{~m}^{3}$, occupying 14 $\mathrm{km}^{2}$, with a main dam length of $625 \mathrm{~m}$ and maximum height of $12.8 \mathrm{~m}$. The reservoir was designed to meet the demands for the irrigation of 156 hectares consisting, predominantly, of vegetable crops (Sena et al., 2020).

Sena et al. (2020) studied water quality variations at the Macela reservoir from 2004 to 2014 and observed that the reservoir water throughout this period remained highly saline and hypereutrophic, characterized as a nutrient-enriched environment $(\mathrm{N}$ and $\mathrm{P}$ ) with high algal production and displaying nitrogen as a limiting nutrient for algal production. The main $\mathrm{N}$ and $\mathrm{P}$ inputs to the reservoir are domestic waste and effluents originating from a variety of small industrial plants (Santos et al., 2013).

The Ribeirópolis reservoir is located in the Ribeirópolis municipality. Its construction by the National Department of Works Against Drought (DNOCS) began in 1947 and was concluded in 1956, by the damming of the Coqueiro stream. It consists of a land-type dam, with a hydrographic extension of $15.5 \mathrm{~km}^{2}$ and an accumulation capacity of $920,000 \mathrm{~m}^{3}$. This reservoir was built to provide water for urban supply and irrigation, but is currently heavily impacted, mainly by domestic sewage, and its waters are unfit for human consumption, bathing or irrigation (Lima \& Garcia, 2008).

According to the Köeppen classification, the climate in the region is the AS' type, consisting of a tropical rainy climate with a dry summer. January exhibits the lowest precipitation rates and June, the highest. The local mean annual temperature is of approximately $26.2^{\circ} \mathrm{C}$ in the dry period and $22.5^{\circ} \mathrm{C}$ in the rainy season, with a mean annual precipitation of $886 \mathrm{~mm}$ (Garcia et al., 2012).

\section{Geology and hydrogeology}

The geology in the reservoir area is represented by the gneissic - migmatite complex of the Itabaiana and Simão Dias Domes. The dominant lithologies in both domes, are banded mylonitic orthogneisses of granitic and granodioritic composition, with boudinated intercalations of amphibolites and gabbros, in some points exhibiting migmatitic features, reflecting several stages of partial anathexia. The most frequent composition of these amphibolite facies orthogneiss includes quartz, potassium feldspar, plagioclase, biotite (hornblende), muscovite, sericite, 
epidote and chlorite (Santos et al., 2001). The Dome of Itabaiana, according to D'el-Rey Silva (1995) comprises a granite-gneissic complex of amphibolite facies surrounded by a metavolcanosedimentary cover of green deformed quartzite, diamictite, phyllite and carbonate facies.

The predominant soils are planossols and luvisols, around the Jacarecica I reservoir, planosols in the Macela reservoir region and luvisols in the Ribeirópolis reservoir area (Bomfim et al., 2002a, 2002b). Planossols are generally shallow, with a sandy surface horizon followed by a dense clayey and not very permeable horizon. Luvisols are also shallow and characterized by a great texture contrast between horizons A and Bt and may present a stony surface. These two classes of soils contain high amounts of primary minerals ( $>80 \%$ are silicates) that are easily weathered (Empresa Brasileira de Pesquisa Agropecuária, 2021).

The predominant hydrogeological domains in the reservoir region are Cristaline and Metasediments/Metavulcanites that present a fractured aquifer behavior. Almost no primary porosity is noted in this type of rock and the occurrence of groundwater is conditioned by secondary porosity represented by fractures and joints. In general, the flows produced by the wells are small and, due to lack of recharge, the effects of the semi-arid climate and the type of rock, the produced waters are, in most cases, brackish (Bomfim et al., 2002a, 2002b).

\section{Sampling and analysis}

Data obtained from the Water Quality Monitoring Program of the Hydrographic Basins of the state of Sergipe (Alves et al., 2018) were used to obtain the following variables: temperature, $\mathrm{pH}$, total dissolved solids, sodium, potassium, calcium, magnesium, chloride, sulfate and bicarbonates. In each reservoir, eight surface water samples were collected at a sampling station at the Jacarecica

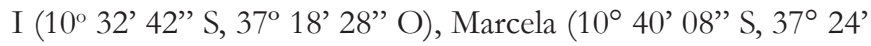
$\left.35^{\prime \prime} \mathrm{O}\right)$ and Ribeirópolis $\left(10^{\circ} 31^{\prime} 17^{\prime \prime} \mathrm{S}, 37^{\circ} 26^{\prime} 20^{\prime \prime} \mathrm{O}\right)$ reservoirs. The sampling stations are located in the liminetic region and depths varied from 9.6 to $11.1 \mathrm{~m}$ for Jacarecica I; 2.5 to $3.1 \mathrm{~m}$ for Macela and 9.8 to $10.0 \mathrm{~m}$ for Ribeirópolis during the sampling period. Eight sampling campaigns were carried out, four in the dry period (August to December) and four in the rainy period (May to July) in the years 2013, 2014, 2017 and 2018. Polyethylene bottles were used, and the samples were stored in ice until arrival at the laboratory. Temperature and $\mathrm{pH}$ were determined in the field, while the other parameters were determined at the Water Laboratory of the Technological and Research Institute of the state of Sergipe (ITPS). Electrical conductivity was determined using a conductivimeter and total dissolved solids were calculated by measuring the electrical conductivity. For ionic composition determinations, the samples were vacuum filtered through 0.45 $\mu \mathrm{m}$ membranes and ionic concentrations were obtained by ion chromatography using a Dionex ICS 3000 ion chromatograph with conductivity detection, following standard methods (American Public Health Association, 2012). The values obtained for each sample are the average of two determinations.

Analysis accuracies were determined using an ionic balance equation:
$A=\left(\frac{\sum \text { cations }-\sum \text { anions }}{\sum \text { cations }+\sum \text { anions }}\right) \times 100$

where $\sum$ cations $=$ sum of the concentrations of $\mathrm{Ca}^{2+}, \mathrm{Mg}^{2+}$, $\mathrm{Na}^{+}$and $\mathrm{K}^{+}$, in meq $\mathrm{L}^{-1}$; $\sum$ anions $=$ sum of the concentrations of $\mathrm{HCO}_{3}^{-}, \mathrm{SO}_{4}^{2-}, \mathrm{Cl}^{-}$in meq $\mathrm{L}^{-1}$ and $\mathrm{A}=$ percentage error of the ionic balance.

The A parameter values for the reservoir samples ranged from $-0.3 \%$ to $-4.8 \%$ for the Macela reservoir, with an absolute mean value of $2.5 \%$, from $+0.3 \%$ to $-5.5 \%$ for the Jacarecica I reservoir, with an absolute mean value of $2.7 \%$ and from $+2.1 \%$ to $+5.5 \%$ for the Ribeirópolis reservoir, with an absolute mean value of $3.0 \%$. These values are in agreement with the absolute mean values reported by Merchán et al. (2015), ranging 2.5\% to $4.4 \%$ in a study carried out on the salinization of an irrigation basin in Spain. According to El Yaouti et al. (2009) an ionic balance error of $\pm 10 \%$ is acceptable for this type of study.

\section{Multivariate statistical analysis}

The Principal Component Analysis (PCA) is a multivariate statistical technique used to reduce the dimensionality of a dataset while maintaining the reliability of the original data. The advantage of applying a PCA to the dataset formed by the collected samples and the variables that define the chemical water characteristics in the evaluated reservoirs is to transform the dataset into new variables, called principal components, which are orthogonal (not correlated) and organized in decreasing order of importance, concentrating the most relevant information in the first principal components (Singh et al., 2004; Shrestha; Kazama, 2007; Zhu et al., 2017). This allows for assessments regarding differences between samples from the same reservoir, between reservoirs, between seasonal periods (dry and rainy) and the identification of possible factors influencing these differences.

The PCA was applied to the data set of the three reservoirs, considering each sample as an object and the determined parameters as variables. The data matrix was composed of 24 objects (eight samples from each reservoir) and 11 variables (temperature, $\mathrm{pH}$, electrical conductivity (EC), total dissolved solids (TDS), $\mathrm{Na}^{+}, \mathrm{K}^{+}$, $\mathrm{Ca}^{2+}, \mathrm{Mg}^{2+}, \mathrm{SO}_{4}^{2-}, \mathrm{Cl}^{-}$and $\mathrm{HCO}_{3}$. The PCA makes it possible to calculate the principal components (PC), the eigenvalues and the percentage of variance associated with each of the components, as well as the loading corresponding to the participation of each parameter in the composition of each PC.

The data were normalized using the $\mathrm{z}$-score technique. In this technique, normalized data exhibit an average of 0 and variance of 1 . Normalization is always recommended in the case of water quality data, which present parameters with very different variances, thereby reducing the influence of parameters displaying high variability (Khalil; Ouarda, 2009).

An ANOVA one way analysis of variance was used assess the occurrence of significant differences between samples from the same reservoir obtained in the dry (August to December) and rainy (May to July) periods.

All tests were performed using the PAST Paleontological Statistics software, version 3.04 (Hammer et al., 2001). A value of 0.05 was adopted as a critical level for all statistical tests, resulting in a $95 \%$ confidence level. 


\section{Geochemical modeling}

The PHREEQC software (United States Geological Survey, 2013), widely applied in this type of hydrogeochemical problem, was used for the geochemical modeling (Merchán et al., 2015; Liu et al., 2017; Barzegar et al., 2018; Liu et al., 2020a). An inverse modeling was applied separately to each studied reservoir and between two selected samples deemed representative of the dataset variability of each reservoir.

In this type of modeling, it is assumed that one of the selected samples (initial sample) interacts with mineral phases and $\mathrm{CO}_{2}$, considering dissolution, precipitation, and ion exchange as possible processes, in order to produce the chemical composition of the other selected sample (final sample) at the end of the modeling.

Based on the lithology mineralogy of the region, the following potential mineral phases were selected using the standard database phreeqc.dat or wateq4f.dat: halite $(\mathrm{NaCl})$, calcite $\left(\mathrm{CaCO}_{3}\right)$, dolomite $\left(\mathrm{CaMg}\left(\mathrm{CO}_{3}\right)_{2}\right)$, gypsum $\left(\mathrm{CaSO}_{4} \cdot 2 \mathrm{H}_{2} \mathrm{O}\right)$, biotite $\left(\mathrm{KMg}_{3} \mathrm{AlSi}_{3} \mathrm{O}_{10}\left(\mathrm{OH}_{2}\right)\right)$, plagioclase $\left(\mathrm{Na}_{0,62} \mathrm{Ca}_{0,38} \mathrm{Al}_{1,38} \mathrm{Si}_{2,62} \mathrm{O}_{8}\right)$ and $\mathrm{K}$-feldspar $\left(\mathrm{KAlSi}_{3} \mathrm{O}_{8}\right)$, and the main ion exchange processes were established as $\mathrm{CaX}_{2}$ and $\mathrm{NaX}$.

The saturation index (SI) of the mineral phases was also calculated, using the PHREEQC thermodynamic database (phreeqc.dat or wateq4f.dat), according to the following equation:

\section{$\mathrm{IS}=\log (\mathrm{PAI} / \mathrm{Kps})$}

where PAI is the product of the ionic activity of the dissolved ions in the solution and Kps is the solubility product of the involved chemical constituents at the sample temperatures.

\section{RESULTS AND DISCUSSIONS}

\section{Reservoir hydrochemistry}

The descriptive statistics of the measured parameters are displayed in Table 1. $\mathrm{pH}$ values ranged from 7.1 to 9.1 with mean values of $8.0 \pm 0.7$ at Jacarecica I, $7.7 \pm 0.4$ at Macela and 8.2 \pm 0.3 at Ribeirópolis, indicating slightly alkaline water samples.
Electrical conductivity (EC) ranged from 219.6 to $2000 \mu \mathrm{S} \mathrm{cm}^{-1}$, with mean values of $399.6 \pm 110.0$ at Jacarecica I, $1166 \pm 342$ at Macela and $1595 \pm 151$ at Ribeirópolis, while the total dissolved solids (TDS) ranged from 123.0 to $1380 \mathrm{mg} \mathrm{L}^{-1}$, averaging 245.3 \pm 76.0 for Jacarecica I, $753.3 \pm 263.6$ for Macela and $1059 \pm 59$ for Ribeirópolis. The higher EC and TDS values at the Macela and Ribeirópolis reservoirs may be due to both being older compared to the Jacarecia I reservoir, and, therefore, displaying a longer water residence time concerning water-rock interactions. This contributes to greater dissolution, leading to increased ionic concentrations (Santos et al., 2000; Singh et al., 2008). The influence of evaporation and anthropogenic impacts cannot be ruled out. Regarding TDS, cations on average constitute about $26 \%$ at the Macela and Ribeirópolis reservoirs and 33\% at the Jacarecica I reservoir, while anions correspond to 50\% at Macela and Ribeirópolis and 70\% in Jacarecica I. According to the Richards diagram (Delgado et al., 2010) which who classifies water for agricultural purposes based on EC values, the investigated reservoir waters present medium (Jacarecica I) and high (Macela, Ribeirópolis) risks of salinization concerning irrigation use.

The reservoir waters presented, on average, a total of cations and anions, respectively, of 81.60 and $171.4 \mathrm{mg} \mathrm{L}^{-1}$ at Jacarecica I; 194.4 and $420.1 \mathrm{mg} \mathrm{L}^{-1}$ at Macela and 279.3 and $542.5 \mathrm{mg} \mathrm{L}^{-1}$ at Ribeirópolis. As a result, the cationic abundance in relation to the total cations was, on average, $\mathrm{Na}^{+}(54 \%)$, followed by $\mathrm{Ca}^{2+}$ (30\%), $\mathrm{Mg}^{2+}(9 \%)$ and $\mathrm{K}^{+}(7 \%)$ at Jacarecica I; $\mathrm{Na}^{+}(60 \%), \mathrm{Ca}^{2+}$ (17\%), $\mathrm{Mg}^{2+}(14 \%)$ and $\mathrm{K}^{+}(9 \%)$ at Macela and $\mathrm{Na}^{+}(55 \%), \mathrm{Ca}^{2+}$ $(20 \%), \mathrm{Mg}^{2+}(20 \%)$ and $\mathrm{K}^{+}(6 \%)$ at Ribeirópolis. On the other hand, in relation to the total anionic content, anions showed, on average, an abundance of $\mathrm{HCO}_{3}^{-}(55 \%), \mathrm{Cl}^{-}(40 \%)$ and $\mathrm{SO}_{4}{ }^{2-}(6 \%)$ at Jacarecica I; $\mathrm{HCO}_{3}^{-}(55 \%), \mathrm{Cl}^{-}(37 \%)$ and $\mathrm{SO}_{4}{ }^{2-}(8 \%)$ at Macela and $\mathrm{Cl}^{-}(61 \%), \mathrm{HCO}_{3}^{-}(37 \%)$ and $\mathrm{SO}_{4}^{2-}(3 \%)$ at Ribeirópolis. No statistically significant differences (ANOVA) were observed concerning the ionic composition between the dry and rainy periods for the three reservoirs.

The PCA applied to the data set revealed that the first two components represent $71.9 \%$ (PC1 55.5\%; PC2 16.4\%) of the information contained in the initial variables. Based on the contribution loading of each variable (Table 2), PC1 is strongly associated (loading $>0.700)$ with most of the larger ions $\left(\mathrm{Na}^{+}, \mathrm{K}^{+}\right.$,

Table 1. Descriptive statistics of the water parameters at the Jacarecica I, Macela and Ribeirópolis reservoirs.

\begin{tabular}{|c|c|c|c|c|c|c|}
\hline \multirow{3}{*}{$\begin{array}{c}\text { Reservoir/ } \\
\text { Parameter }\end{array}$} & \multirow{2}{*}{\multicolumn{2}{|c|}{$\begin{array}{c}\text { Jacarecica I } \\
\mathrm{N}=8\end{array}$}} & \multirow{2}{*}{\multicolumn{2}{|c|}{$\begin{array}{c}\text { Macela } \\
\mathbf{N}=8\end{array}$}} & \multicolumn{2}{|c|}{ Ribeirópolis } \\
\hline & & & & & & \\
\hline & Min-Max & Means \pm sd & Min-Max & Means \pm sd & Min-Max & Means \pm sd \\
\hline $\mathrm{pH}$ & 7.1-9.1 & $8.0 \pm 0.7$ & $7.3-8.4$ & $7.7 \pm 0.4$ & $7.9-8.8$ & $8.2 \pm 0.3$ \\
\hline $\mathrm{T}\left({ }^{\circ} \mathrm{C}\right)$ & $25.0-29.0$ & $26.7 \pm 1.7$ & $21.1-28.0$ & $26.0 \pm 2.2$ & $23.8-30.4$ & $26.6 \pm 2.0$ \\
\hline $\mathrm{EC}\left(\mu \mathrm{S} \mathrm{cm}^{-1}\right)$ & $219.6-536.9$ & $399.6 \pm 110.0$ & $972.2-2000$ & $1166 \pm 342$ & 1411-1866 & $1595 \pm 151$ \\
\hline TDS $\left(\mathrm{mg} \mathrm{L}^{-1}\right)$ & $123.0-332.0$ & $245.3 \pm 76.0$ & $594.2-1380$ & $753.3 \pm 263.6$ & $972.8-1150$ & $1059 \pm 59$ \\
\hline $\mathrm{Na}^{+}\left(\mathrm{mg} \mathrm{L}^{-1}\right)$ & $28.73-63.47$ & $44.20 \pm 11.90$ & $82.60-138.0$ & $116.7 \pm 17.7$ & $119.0-182.2$ & $154.7 \pm 19.4$ \\
\hline $\mathrm{K}^{+}\left(\mathrm{mg} \mathrm{L}^{-1}\right)$ & $1.30-34.29$ & $9.30 \pm 10.30$ & $11.68-31.55$ & $17.67 \pm 6.24$ & $11.00-18.50$ & $15.23 \pm 3.33$ \\
\hline $\mathrm{Ca}^{2+}\left(\mathrm{mg} \mathrm{L}^{-1}\right)$ & $1.66-45.81$ & $23.20 \pm 14.90$ & $26.97-93.90$ & $39.92 \pm 22.20$ & $35.84-67.92$ & $54.86 \pm 14.06$ \\
\hline $\mathrm{Mg}^{2+}\left(\mathrm{mg} \mathrm{L}^{-1}\right)$ & $3.84-19.45$ & $9.80 \pm 5.50$ & $17.72-34.30$ & $26.83 \pm 6.48$ & $34.68-79.00$ & $54.57 \pm 16.29$ \\
\hline $\mathrm{SO}_{4}^{2-}\left(\mathrm{mg} \mathrm{L}^{-1}\right)$ & $1.60-71.09$ & $16.40 \pm 23.00$ & $24.02-43.11$ & $34.69 \pm 6.80$ & $6.38-21.10$ & $14.29 \pm 4.35$ \\
\hline $\mathrm{Cl}^{-}\left(\mathrm{mg} \mathrm{L}^{-1}\right)$ & 38.46-91.18 & $68.20 \pm 19.10$ & $114.2-259.7$ & $168.0 \pm 43.1$ & $275.4-404.3$ & $328.5 \pm 57.8$ \\
\hline $\mathrm{HCO}_{3}^{-}\left(\mathrm{mg} \mathrm{L}^{-1}\right)$ & $57.95-170.6$ & $101.4 \pm 35.8$ & $192.7-289.7$ & $229.9 \pm 34.2$ & $182.8-224.1$ & $199.7 \pm 13.1$ \\
\hline
\end{tabular}

$\mathrm{N}=$ samples number; $\mathrm{EC}=$ electrical conductivity; TDS = total dissolved solids. Minimum (Min), maximum (Max) and means \pm standard deviation (Mean \pm sd). 


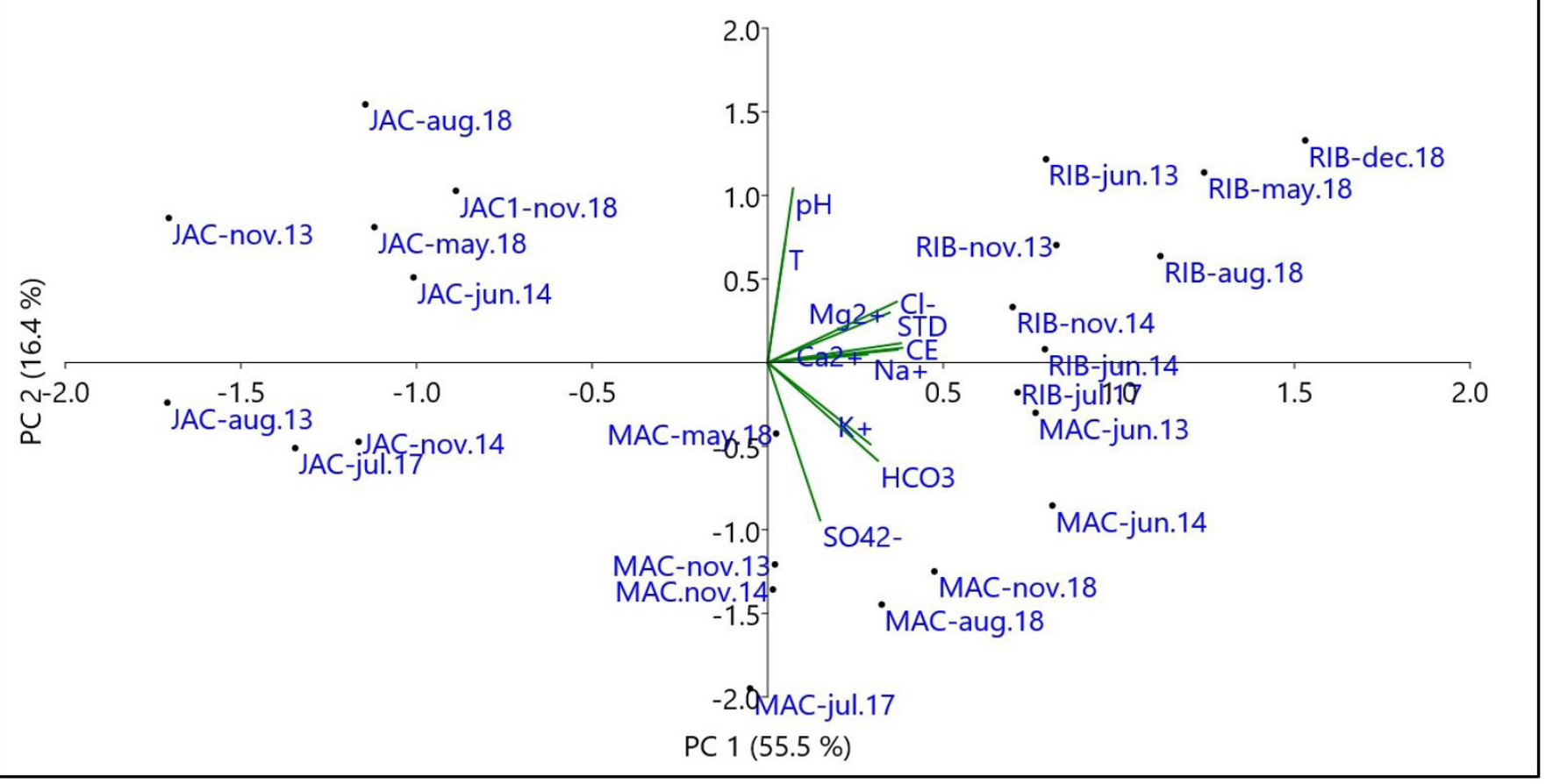

Figure 2. Location of the reservoir samples in the plane formed by the first two main components PC 1 x PC 2 . The projection of the original variables is displayed in green. Sample code $=$ name of the reservoir-month.year of sampling. JAC = Jacarecica I; MAC $=$ Macela; RIB = Ribeirópolis.

$\mathrm{Mg}^{2+}, \mathrm{Ca}^{2+}, \mathrm{HCO}_{3}, \mathrm{Cl}$ ), which are the most relevant contributors to $\mathrm{EC}$ and TDS, representing the natural hydrogeochemical evolution of water-rock interactions (Yan et al., 2016; Liu et al., 2017). PC2 displayed a strong positive association with $\mathrm{pH}$ (loading $=0.765)$ and a moderate negative association with $\mathrm{SO}_{4}^{2-}$ (loading $=-0.695$ ).

Figure 2 presents the location of the samples in the plane formed by PC1 and PC2. The projection of the original variables (in green) was also included to allow visualizing of the degree of participation of each original variable in the composition of the principal components.

The plane formed by PC1 and PC2 (Figure 2) separated the samples from the three reservoirs into three different groups. The group formed by samples from the Jacarecica I reservoir is located in the negative region of PC1 and separated from the samples from the other reservoirs, as they exhibited lower ionic concentrations, i.e., lower TDS values.

In general, the group formed by samples from the Ribeirópolis reservoir occupied the positive region of PC1 and PC2, while the group of samples from the Macela reservoir was distributed in the positive region of PC1 and negative region of PC2. The projection of the original variables (in green) indicates that the samples located on the positive side of PC2 present higher $\mathrm{pH}, \mathrm{T}, \mathrm{Mg}^{2+}, \mathrm{Cl}$, TDS, $\mathrm{CE}, \mathrm{Ca}^{2+}$ and $\mathrm{Na}^{+}$values, while samples located on the negative side of $\mathrm{PC} 2$ present higher $\mathrm{K}^{+}$, $\mathrm{HCO}_{3}{ }_{3}^{-}$and $\mathrm{SO}_{4}{ }^{2-}$ concentrations. Therefore, the samples from the Ribeirópolis reservoir presented higher $\mathrm{pH}, \mathrm{T}, \mathrm{Mg}^{2+}, \mathrm{Cl}^{-}$, TDS, EC, $\mathrm{Ca}^{2+}$ and $\mathrm{Na}^{+}$values compared to the Macela reservoir and lower $\mathrm{K}^{+}, \mathrm{HCO}_{3}^{-}$and $\mathrm{SO}_{4}^{2-}$ concentrations, and because of this, were separated by PC2. It is important to note that, considering variable
Table 2. Experimental parameter loadings for the first two main components.

\begin{tabular}{lcc}
\hline \multicolumn{1}{c}{ Parameter } & PC $\mathbf{1}$ & PC 2 \\
\hline $\mathrm{pH}$ & 0.179 & $\mathbf{0 . 7 6 5}$ \\
$\mathrm{T}\left({ }^{\circ} \mathrm{C}\right)$ & 0.123 & 0.523 \\
$\mathrm{EC}\left(\mu \mathrm{S} \mathrm{cm}^{-1}\right)$ & $\mathbf{0 . 9 5 9}$ & 0.065 \\
$\mathrm{TDS}\left(\mathrm{mg} \mathrm{L}^{-1}\right)$ & $\mathbf{0 . 9 4 9}$ & 0.085 \\
$\mathrm{Na}^{+}\left(\mathrm{mg} \mathrm{L}^{-1}\right)$ & $\mathbf{0 . 9 2 5}$ & 0.057 \\
$\mathrm{~K}^{+}\left(\mathrm{mg} \mathrm{L}^{-1}\right)$ & $\mathbf{0 . 7 3 1}$ & -0.360 \\
$\mathrm{Ca}^{2+}\left(\mathrm{mg} \mathrm{L}^{-1}\right)$ & $\mathbf{0 . 7 1 1}$ & 0.036 \\
$\mathrm{Mg}^{2+}\left(\mathrm{mg} \mathrm{L}^{-1}\right)$ & $\mathbf{0 . 8 6 8}$ & 0.220 \\
$\mathrm{SO}_{4}^{2-}\left(\mathrm{mg} \mathrm{L}^{-1}\right)$ & 0.373 & $\mathbf{- 0 . 6 9 5}$ \\
$\mathrm{Cl}^{-}\left(\mathrm{mg} \mathrm{L}^{-1}\right)$ & $\mathbf{0 . 9 1 9}$ & 0.268 \\
$\mathrm{HCO}_{3}^{-}\left(\mathrm{mg} \mathrm{L}^{-1}\right)$ & $\mathbf{0 . 7 8 4}$ & -0.433 \\
Total variance $(\%)$ & 55.5 & 16.4 \\
Cumulative variance $(\%)$ & 55.5 & 71.9 \\
\hline
\end{tabular}

loading (Table 2), the parameters that most contributed to data separation were $\mathrm{pH}$ (loading $=0.765)$ and $\mathrm{SO}_{4}^{2-}$ (loading $\left.=-0.695\right)$.

\section{Reservoir hydrogeochemistry}

The Gibbs diagram is widely applied to identify the influence of atmospheric precipitation, weathering and evaporation processes on chemical water composition (Gibbs, 1970).

The diagram is constructed by plotting the $\mathrm{Na}^{+} /\left(\mathrm{Na}^{+}+\mathrm{Ca}^{2+}\right)$ ratios as a function of TDS and is shaped like a "boomerang". Waters with medium (70 to $300 \mathrm{mg} \mathrm{L}^{-1}$ ) and low salinity and with 
$\mathrm{Na}^{+} /\left(\mathrm{Na}^{+}+\mathrm{Ca}^{2+}\right)<0.5$, are located to the left of the middle part of the "boomerang", because they contain higher $\mathrm{Ca}^{2+}$ and $\mathrm{HCO}_{3}{ }^{-}$concentrations compared to $\mathrm{Na}^{+}$and $\mathrm{Cl}$, indicating that the final dominant mechanism is weathering. Waters with a high $\mathrm{Na}^{+} /\left(\mathrm{Na}^{+}+\mathrm{Ca}^{2+}\right)$ ratios (approximately 1.0) are distributed at the ends of the "boomerang" and may result from salinization due to evaporation (upper right) or are less saline due to the influence of recent precipitation (lower right) and have not yet had enough contact with minerals for geochemical modifications to occur (Marandi \& Shand, 2018).

The reservoir samples were positioned in the central part of the diagram (Figure 3), indicating water-rock interactions as the main mechanisms responsible for their chemical characteristics. The samples are also displaced to the right $\left.\left(\mathrm{Na}^{+} / \mathrm{Na}^{+}+\mathrm{Ca}^{2+}\right)>0.4\right)$ and samples from the Ribeirópolis reservoir reached the limit line of the weathering region. This displacement can be caused by increased weathering and/or evaporation, leading to a greater relative abundance of $\mathrm{Na}^{+}$(Marandi \& Shand, 2018; Liu et al., 2020b). Evaporation effects are probably more pronounced at the Macela and Ribeirópolis reservoirs, since they were built thirty years before Jacarecica I, and their waters being less used due to the high TDS concentrations.

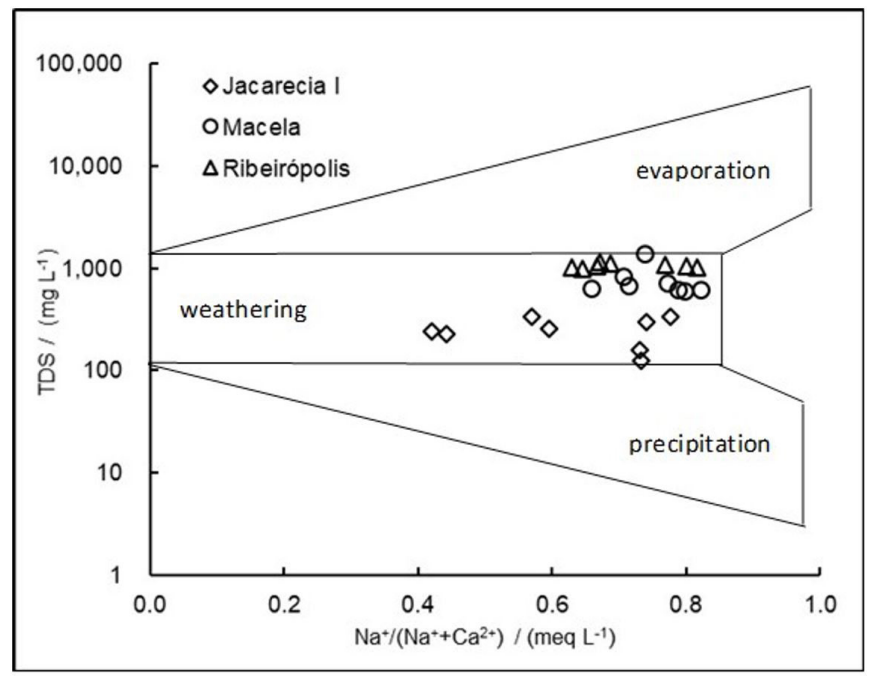

Figure 3. Gibbs diagram displaying the evaluated reservoir samples.
To evaluate hydrogeochemical processes, statistical correlation analysis, ionic ratios and inverse geochemical modeling using PHREEQC were applied. The combination of these three methods has been effective in identifying sources and geochemical processes involved in the ionic composition of waters (Han et al., 2014; Singh et al., 2017; Liu et al., 2020c).

The correlation analysis was calculated parallel to the PCA, using the same data matrix. The correlation matrix (Table 3) indicates that TDS correlates strongly $(\mathrm{r}>0.700)$ with $\mathrm{Na}^{+}, \mathrm{Ca}^{2+}$, $\mathrm{Mg}^{2+}$ and $\mathrm{Cl}^{-}$indicating that these ions are the most important in water mineralization control, and that the concentrations of these ions tend to increase with the increasing salinization (increases in TDS). The fact that TDS do not correlate with $\mathrm{pH}$ suggests that the dissolution of minerals is not related to water acid-base conditions (Manno et al., 2006).

The strong correlation between $\mathrm{Na}^{+}$and $\mathrm{Cl}^{-}(\mathrm{r}=0.901)$ suggests that these ions have the same origin, and as the reservoir region is close to the coast, the main source should be marine aerosol. $\mathrm{HCO}_{3}{ }^{-}$was correlated with $\mathrm{Ca}^{2+}(\mathrm{r}=0.400)$ and $\mathrm{Mg}^{2+}$ $(r=0.531)$, lower than expected for carbonate cations, which may reflect that the predominant origin of these ions is silicate weathering and not carbonate dissolution (Gaillardet et al., 1999; Morán-Ramírez et al., 2016).

$\mathrm{K}^{+}$presented a strong correlation with $\mathrm{HCO}_{3}^{-}(\mathrm{r}=0,777)$ and a moderate correlation with $\mathrm{Mg}^{2+}(\mathrm{r}=0,629)$, which can be attributed to the change from biotite to kaolinite that generates these ions as a by-product (Drever, 1982). The correlations between $\mathrm{K}^{+}$and $\mathrm{SO}_{4}^{2-}$ and $\mathrm{Cl}^{-}$may also indicate the impact of fertilizer use (El Alfy et al., 2017).

Ionic ratios in the hydrochemical data have been widely applied to provide an insight into the hydrogeochemical processes controlling the water ionic composition. (Merchán et al., 2015; Barzegar et al., 2018; Guo et al., 2018; Zhang et al., 2018; Jia et al., 2020; Liu et al., 2020b).

Chloride, in general, is present in common rock types, at lower values than any of the other major ionic constituents of natural water (Sharma et al., 2012). Generally, most $\mathrm{Cl}^{-}$originates from an atmospheric source or from sea water, and the primary lithogenic source of $\mathrm{Cl}^{-}$is the weathering of halite and evaporites. To evaluate the contribution of these sources, the relationship between $\mathrm{Na}^{+}$and $\mathrm{Cl}^{-}$was compared with the halite $\mathrm{Na}^{+} / \mathrm{Cl}^{-}\left(1.0\right.$ meq $\left.\mathrm{L}^{-1}\right)$ and marine aerosol $\left(0.85 \mathrm{meq} \mathrm{L}^{-1}\right)$ ratios, while ratios much higher

Table 3. Spearman (r) correlation matrix for the Jacarecica I, Macela and Ribeirópolis reservoir samples (significant values are highlighted in bold).

\begin{tabular}{|c|c|c|c|c|c|c|c|c|c|c|}
\hline Correlation & $\mathrm{pH}$ & EC & TDS & $\mathrm{Na}^{+}$ & $\mathbf{K}^{+}$ & $\mathrm{Ca}^{2+}$ & $\mathrm{Mg}^{2+}$ & $\mathrm{SO}_{4}^{2-}$ & $\mathrm{Cl}^{-}$ & $\mathrm{HCO}_{3}$ \\
\hline $\mathrm{pH}$ & 1 & & & & & & & & & \\
\hline $\mathrm{CE}$ & 0.321 & 1 & & & & & & & & \\
\hline TDS & 0.320 & 0.990 & 1 & & & & & & & \\
\hline $\mathrm{Na}^{+}$ & 0.221 & 0.830 & 0.820 & 1 & & & & & & \\
\hline $\mathrm{K}^{+}$ & -0.077 & 0.672 & 0.687 & 0.655 & 1 & & & & & \\
\hline $\mathrm{Ca}^{2+}$ & 0.198 & 0.696 & 0.722 & 0.473 & 0.460 & 1 & & & & \\
\hline $\mathrm{Mg}^{2+}$ & 0.191 & 0.871 & 0.880 & 0.832 & 0.629 & 0.697 & 1 & & & \\
\hline $\mathrm{SO}_{4}^{2-}$ & -0.296 & 0.302 & 0.280 & 0.154 & 0.497 & 0.206 & 0.191 & 1 & & \\
\hline $\mathrm{Cl}^{-}$ & 0.189 & 0.908 & 0.901 & 0.901 & 0.665 & 0.697 & 0.950 & 0.133 & 1 & \\
\hline $\mathrm{HCO}_{3}^{-}$ & -0.092 & 0.585 & 0.605 & 0.604 & 0.777 & 0.400 & 0.531 & 0.612 & 0.546 & 1 \\
\hline
\end{tabular}


than these values may indicate greater weathering contribution of minerals that form rocks and anthropogenic sources (Singh et al., 2005; Sharma et al., 2012; Morán-Ramírez et al., 2016).

Figure $4 \mathrm{a}$ indicates $\mathrm{Na}^{+}$and $\mathrm{Cl}^{-}$ratio for the reservoir samples, where line 1:0.85 was included, which corresponds to the relationship regarding atmospheric precipitation (marine aerosol dissolved in rainwater). Line 1:1 marks the relationship of the halite that makes up the sea salt sedimented in the soil with dry deposition (atmospheric material transport and deposition without the presence of rain) and which is dissolved by rainwater and drained into surface waters (Drever, 1982). The Jacarecica I samples were positioned close to the 1:0.85 and 1:1 line confirming, respectively, marine aerosol carried by atmospheric precipitation and dry deposition as the main $\mathrm{Cl}^{-}$and $\mathrm{Na}^{+}$sources. The samples from the Macela reservoir were above the 1:1 line, while most samples from the Ribeirópolis reservoir were below the 1:0.85 line. Samples above and below these lines indicate that $\mathrm{Na}^{+}$ concentrations in water are, respectively, higher and lower than
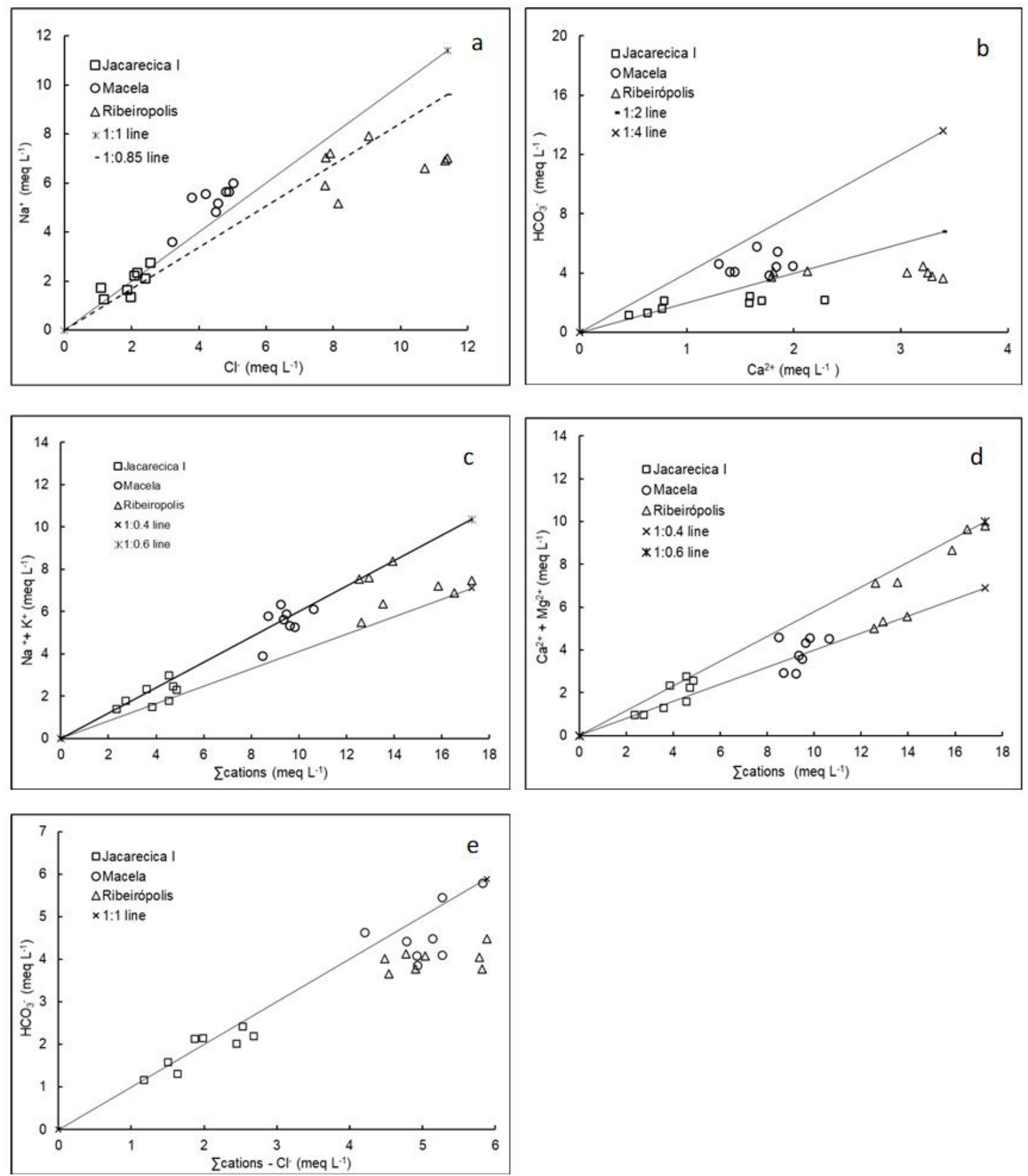

Figure 4. Dispersion graphs: (a) $\mathrm{Na}^{+}$vs $\mathrm{Cl}^{-}$; (b) $\mathrm{Ca}^{2+}+\mathrm{Mg}^{2+}$ vs $\mathrm{HCO}_{3}^{-}$; (c) $\mathrm{Na}^{+}+\mathrm{K}^{+}$vs $\sum$ cations; (d) $\mathrm{Ca}^{2+}+\mathrm{Mg}^{2+}$ vs $\sum$ cations; (e) $\mathrm{HCO}_{3}^{-}$vs $\sum$ cations. 
expected values if marine aerosol were the only source of $\mathrm{Na}^{+}$and therefore, the ion exchange process may also be involved in the control of $\mathrm{Na}^{+}$concentrations. In the case of samples above the 1:1 line, the contribution of anthropogenic sources is not excluded, including drainage of agricultural areas and the contribution of both domestic and industrial waste (Morán-Ramírez et al., 2016).

Ion exchange with clay materials is usually observed when the water is being salinized (Slama \& Bouhlila, 2017). During direct ion exchange, $\mathrm{Na}^{+}$ions from the surface of the clay minerals $(\mathrm{X})$ are displaced by $\mathrm{Ca}^{2+}$ ions present in the water (Equation 1), while in reverse ion exchange processes, the $\mathrm{Ca}^{2+}$ ions present in clay minerals are exchanged for $\mathrm{Na}^{+}$ions from the water (Equation 2). Therefore, $\mathrm{Na}^{+}$water enrichment is noted during direct ion exchange accompanied by decreased $\mathrm{Ca}^{2+}$ concentrations, while the opposite occurs during reverse ion exchange processes, of decreased $\mathrm{Na}^{+}$and increased $\mathrm{Ca}^{2+}$ concentrations.

$2 \mathrm{NaX}+\mathrm{Ca}^{2+} \rightarrow 2 \mathrm{Na}^{+}+\mathrm{CaX}_{2}$

$\mathrm{CaX}_{2}+2 \mathrm{Na}^{+} \rightarrow \mathrm{Ca}^{2+}+2 \mathrm{NaX}$

According to El Yaouti et al. (2009), $\mathrm{Na}^{+} / \mathrm{Ca}^{2+}$ ratios on the clay surface and in the water determine the type of ion exchange. Thus, when $\mathrm{Na}^{+} / \mathrm{Ca}^{2+}$ ratios on the clay surface are greater than in water, direct ion exchange occurs, and when this ratio is higher in water compared to the clay surface, reverse ion exchange takes place.

The relationship between $\left(\mathrm{Na}^{+}-\mathrm{Cl}\right)$ and $\left(\mathrm{Ca}^{2+}+\mathrm{Mg}^{2+}\right)$ $-\left(\mathrm{SO}_{4}{ }^{2-}-\mathrm{HCO}_{3}{ }^{-}\right)$has been applied to verify the hypothesis that ion exchange is a relevant geochemical process. This relationship represents the amount of $\mathrm{Na}^{+}, \mathrm{Ca}^{2+}$ and/or $\mathrm{Mg}^{2+}$ gained or lost from other sources, except for halite, calcite, dolomite and gypsum dissolutions. If ion exchange is a dominant process, the relationship between these parameters must be linear, with the slope close to -1.0. (Farid et al., 2015; Jia et al., 2020). Associations with a slope of $-0.96\left(\mathrm{r}^{2}=0.90\right)$ for the Macela reservoir and a slope of $-1.03\left(\mathrm{r}^{2}=0.90\right)$ for the Ribeirópolis reservoir were noted, indicating that ion exchange is a relevant process at these reservoirs. The linear correlation was low $\left(r^{2}=0.64\right)$ for the Jacarecica I reservoir samples, suggesting that, in this case, ion exchange is not a significant contributor.

$\mathrm{K}^{+}$may also originate from atmospheric precipitation and/ or weathering from silicates rich in this element. The average $\mathrm{K}^{+} /$ $\mathrm{Cl}^{-}$ratios in meq $\mathrm{L}^{-1}$ for the waters of the Jacarecica $\mathrm{I}(0.07 \pm 0.02)$, Macela $(0.10 \pm 0.03)$ and Ribeirópolis $(0.04 \pm 0.01)$ reservoirs were higher than that of marine aerosol (0.02), suggesting is a relevant contribution of silicate weathering to $\mathrm{K}^{+}$concentrations to the water of the three reservoirs (Sharma et al., 2012).

Potential $\mathrm{SO}_{4}^{2-}$ sources comprise atmospheric precipitation, gypsum or anhydrite dissolution and pyrite oxidation, which may also undergo some contribution from anthropogenic inputs (Gaillardet et al., 1999; Morán-Ramírez et al., 2016). The average $\mathrm{SO}_{4}^{2-} / \mathrm{Cl}^{-}$ratio was $0.101 \pm 0.072 \mathrm{meq} \mathrm{L}^{-1}$, which is equivalent to the ratio of the marine aerosol $\left(0.104 \mathrm{meq} \mathrm{L}^{-1}\right)$, therefore suggesting that atmospheric precipitation should be the main source of $\mathrm{SO}_{4}^{2-}$ for the water from the three reservoirs.

Carbonate weathering is an important source of $\mathrm{Ca}^{2+}, \mathrm{Mg}^{2+}$ and $\mathrm{HCO}_{3}^{-}$(Mosaad et al., 2019; Guo et al., 2018). When a calcite contribution is predominant, the water $\mathrm{HCO}_{3}^{-} / \mathrm{Ca}^{2+}$ ratio is equal to 2 (Equation 3), while predominant dolomite contributions lead to a ratio of 4 (Equation 4).

$$
\mathrm{CaCO}_{3}+\mathrm{H}_{2} \mathrm{CO}_{3} \rightarrow \mathrm{Ca}^{2+}+2 \mathrm{HCO}_{3}^{-}
$$

$\mathrm{CaMg}\left(\mathrm{CO}_{3}\right)_{2}+2 \mathrm{H}_{2} \mathrm{CO}_{3} \rightarrow \mathrm{Ca}^{2+}+\mathrm{Mg}^{2+}+4 \mathrm{HCO}_{3}^{-}$

The samples from the Macela reservoir are distributed between lines 1:2 and 1:4 (Figure 4b), while some samples were located below these two lines for the Jacarecica I and Ribeirópolis reservoirs. The sample projections in the zone between the two lines indicates that both calcite and dolomite probably dissolved, while the samples located in the zone below the two lines suggest excess $\mathrm{Ca}^{2+}$, originated from sources other than carbonates. When carbonated rocks are the main source of $\mathrm{Ca}^{2+}, \mathrm{Mg}^{2+}$ and $\mathrm{HCO}_{3}^{-}$, the molar ratios of these ions with $\mathrm{Na}^{+}$are high $\left(\mathrm{Ca}^{2+} / \mathrm{Na}^{+} \approx 50\right.$, $\left.\mathrm{Mg}^{2+} / \mathrm{Na}^{+} \approx 10, \mathrm{HCO}_{3}^{-} / \mathrm{Na}^{+} \approx 120\right)$, becoming low $\left(\mathrm{Ca}^{2+} / \mathrm{Na}^{+} \approx\right.$ $0,35, \mathrm{Mg}^{2+} / \mathrm{Na}^{+} \approx 0,24, \mathrm{HCO}_{3}^{-} / \mathrm{Na}^{+} \approx 2$ ) when the predominant source is silicate (Gaillardet et al., 1999; Morán-Ramírez et al., 2016). In the investigated reservoirs, molar ratios ranged from 0.11 to 0.69 , averaging $0.24 \pm 0.15$, for $\mathrm{Ca}^{2+} / \mathrm{Na}^{+}$, from 0.09 to 0.48 , averaging $0.25 \pm 0.11$, for $\mathrm{Mg}^{2+} / \mathrm{Na}^{+}$, and from 0.24 to 0.79 , averaging $0.42 \pm 0.14$, for $\mathrm{o} \mathrm{HCO}_{3}^{-} / \mathrm{Na}^{+}$, indicating that silicate contribution is more relevant than carbonate contribution.

Silicate weathering corresponds to the dissolution or alteration of the minerals present in the bedrock and is more difficult to evaluate, as they degrade incongruently, generating solid phases (usually clays) alongside dissolved ionic species (Drever, 1982; Das \& Kaur, 2001; Subramani et al., 2010). In general, $\left(\mathrm{Na}^{+}+\right.$ $\left.\mathrm{K}^{+}\right)$and $\left(\mathrm{Ca}^{2+}+\mathrm{Mg}^{2+}\right)$ ratios to total cations ( $\sum$ cations) generated in silicate degradation reactions have been applied to understand silicate weathering contributions (Kim, 2003; Barzegar et al., 2018).

Figures $4 \mathrm{c}$ and $4 \mathrm{~d}$ demonstrate that the reservoir samples were distributed close to lines 1:0.4 and 1:0.6, which correspond to Equations 5 and 6, respectively (Drever, 1982). This means that the water in the reservoirs, enriched with atmospheric $\mathrm{CO}_{2}$, reacts with the host rock silicates, specifically plagioclase $\left(\mathrm{Na}_{0.62} \mathrm{Ca}_{0.38} \mathrm{Al}_{1,38} \mathrm{Si}_{2.62} \mathrm{O}_{8}\right)$, feldspar $\left(\mathrm{KAlSi}_{3} \mathrm{O}_{8}\right)$ and biotite $\left(\mathrm{KMg}_{3} \mathrm{AlSi}_{3} \mathrm{O}_{10}(\mathrm{OH})_{2}\right)$, leaching $\mathrm{Na}^{+}, \mathrm{K}^{+}, \mathrm{Ca}^{2+}, \mathrm{Mg}^{2+}$ and $\mathrm{HCO}_{3}^{-}$and converting to kaolinite $\left(\mathrm{Al}_{2} \mathrm{Si}_{2} \mathrm{O}_{5}(\mathrm{OH})_{4}\right)$, smectite $\left(\mathrm{Ca}_{0.17} \mathrm{Al}_{2.33} \mathrm{Si}_{3.67} \mathrm{O}_{10}(\mathrm{OH})_{2}\right)$ and silica $\left(\mathrm{SiO}_{2}\right)$.

$$
\begin{aligned}
& 177 \mathrm{Na}_{0.62} \mathrm{Ca}_{0.38} \mathrm{Al}_{1.38} \mathrm{Si}_{2.62} \mathrm{O}_{8}+7.3 \mathrm{KMg}_{3} \mathrm{AlSi}_{3} \mathrm{O}_{10}(\mathrm{OH})_{2}+ \\
& 13 \mathrm{KAlSi}_{3} \mathrm{O}_{8}+412.5 \mathrm{H}_{2} \mathrm{O}+310 \mathrm{CO}_{2}=133 \mathrm{Al}_{2} \mathrm{Si}_{2} \mathrm{O}_{5}(\mathrm{OH})_{4}{ }^{+} \\
& 110 \mathrm{Na}^{+}+68 \mathrm{Ca}^{2+}+22 \mathrm{Mg}^{2+}+20 \mathrm{~K}^{+}+270 \mathrm{SiO}_{2}+310 \mathrm{HCO}_{3}^{-}
\end{aligned}
$$

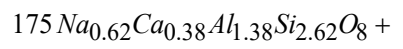
$14 \mathrm{KMg}_{3} \mathrm{AlSi}_{3} \mathrm{O}_{10}(\mathrm{OH})_{2}+115 \mathrm{CaCO}_{3}+$ $404 \mathrm{H}_{2} \mathrm{O}+427 \mathrm{CO}_{2}=81 \mathrm{Ca}_{0.17} \mathrm{Al}_{2.33} \mathrm{Si}_{3.67} \mathrm{O}_{10}(\mathrm{OH})_{2}+$ $33 \mathrm{Al}_{2} \mathrm{Si}_{2} \mathrm{O}_{5}(\mathrm{OH})_{4}+109 \mathrm{Na}^{+}+167 \mathrm{Ca}^{2+}+42 \mathrm{Mg}^{2+}+$ $12 \mathrm{~K}^{+}+137 \mathrm{SiO}_{2}+539 \mathrm{HCO}_{3}^{-}$

Figure $4 \mathrm{c}$ evaluates silicate participation to $\mathrm{Na}^{+}$and $\mathrm{K}^{+}$ concentrations. The Jacarecica I and Ribeiropólis reservoir samples were distributed on lines 1:0.4 and 1:0.6 suggesting the plagioclase, 
biotite and K-feldspar contributions (Equations 5 and 6), while the vast majority of samples from the Macela reservoir were positioned on line 1:0.6, indicating a high plagioclase and biotite contribution (Equation 6).

Regarding $\mathrm{Ca}^{2+}$ and $\mathrm{Mg}^{2+}$ concentrations (Figure 4d), the Jacarecica I and Ribeiropólis samples were distributed on lines 1:0.4 and 1:0.6, indicating that silicate participation occurs through the interaction of plagioclase and biotite, with calcite dissolution also occurring (Equations 5 and 6), while most samples from the Macela reservoir were positioned around the 1:0.4 line, suggesting the predominant contribution of plagioclase and biotite (Equation 5).

The assessment presented herein for silicate weathering in the three reservoirs is consistent with the weathering results of some springs in Sierra Nevada, California (Garrels \& Mackenzie, 1967; Drever, 1982). Drever (1982) comments that ions dissolved in water $\left(\mathrm{Na}^{+}, \mathrm{K}^{+}, \mathrm{Ca}^{2+}, \mathrm{Mg}^{2+}\right)$ resulted almost entirely from the reaction of $\mathrm{CO}_{2}$ dissolved in water containing silicates (plagioclase, biotite and feldspar), with kaolinite as its main product, which may lead to also the formation of smectite.

Hydrogeochemical processes similar to those observed for the studied reservoirs were identified in the surface and groundwater in other regions (Sharma et al., 2012; Morán-Ramírez et al., 2016; Barzegar et al., 2018). In the surface waters of the Mahi River basin in western India, for example, weathering of aluminum-silicate minerals was considered the main source of $\mathrm{Na}^{+}, \mathrm{K}^{+}, \mathrm{Ca}^{2+}, \mathrm{Mg}^{2+}$ and $\mathrm{HCO}_{3}^{-}$, with a small contribution from carbonate dissolution to $\mathrm{Ca}^{2+}$ and $\mathrm{Mg}^{2+} . \mathrm{Na}^{+}, \mathrm{K}^{+}, \mathrm{Cl}^{-}$and $\mathrm{SO}_{4}^{2-}$ inputs from marine and anthropogenic sources were also observed (Sharma et al., 2012).

In the Khoy Plain, in northwest Iran, Barzegar et al. (2018) demonstrated silicate weathering (albite, orthoclase and microcline) as the main source of $\mathrm{Na}^{+}$and $\mathrm{K}^{+}$, release to groundwater, while for $\mathrm{Ca}^{2+}$ and $\mathrm{Mg}^{2+}$, the most important contributions comprised carbonate dissolution. The authors also highlighted the importance of the ion exchange process in controlling $\mathrm{Na}^{+}$ and $\mathrm{Ca}^{2+}$ concentrations.

For aquifers in the Guadalajara system in Mexico, anthropogenic impacts were identified as the primary source of $\mathrm{Cl}^{-}$and $\mathrm{SO}_{4}^{2-}$. On the other hand, the primary origin of $\mathrm{Na}^{+}$and $\mathrm{K}^{+}$was silicate weathering (plagioclase and $\mathrm{K}$-feldspar), while for $\mathrm{Ca}^{2+}$ and $\mathrm{Mg}^{2+}$, the most relevant contribution was carbonate dissolution (Morán-Ramírez et al., 2016).

The impact of anthropogenic activities on chemical water composition has been assessed by the relationship between $\mathrm{HCO}_{3}{ }^{-}$and the sum of the largest cations ( $\sum$ cations $\left.=\left[\left(\mathrm{Na}^{+}+\mathrm{K}^{+}+\mathrm{Ca}^{2+}+\mathrm{Mg}^{2+}\right)-\mathrm{Cl}^{-}\right]\right)$. The subtraction of $\mathrm{Cl}^{-}$is to eliminate the effect of salts like $\mathrm{NaCl}$ and $\mathrm{CaCl}_{2}$ in order to represent only the dissolution of minerals like carbonates and silicates (Kim, 2003; Barzegar et al., 2018).

Figure $4 \mathrm{e}$ displays the dispersion of the reservoir samples on the $\mathrm{HCO}_{3}^{-}-\sum$ cation graph. Samples located at the 1:1 line represent the distribution of ions originating only from carbonate and silicate weathering (Barzegar et al., 2018). Urban, industrial and agricultural dumping can contribute to the ionic composition resulting in deviations from the 1:1 line. Therefore, Figure 4e suggest the occurrence of anthropogenic impacts in the Macela and Ribeirópolis reservoirs, where almost all samples were located below the 1:1 line. The agricultural activity area is downstream from the Jacarecica I reservoir, so irrigation return did not result in significant impacts on the reservoir. At the other two reservoirs, the greatest impacts comprise urban and industrial dumping (Sena et al., 2020; Lima \& Garcia, 2008).

\section{Geochemical modeling}

Hydrogeochemical modeling allows for the calculation of the chemical balance between minerals and water, allowing for predictions concerning different geochemical processes, as well as the sources that control the ion concentrations in the water.

No reverse geochemical modeling studies were found in the literature concerning surface water in reservoirs, as, in general, most published works deal with groundwater. An application of reverse modeling to surface water was described by Merchán et al. (2015), who applied inverse modeling for the Lerma/Spain basin, using a spring water sample and a superficial water sample from the basin, collected from different periods, assuming that they are connected by a flow line. In this study, the inverse geochemical modeling using PHREEQC (United States Geological Survey, 2013), was applied between two water samples from each reservoir considered representative of the dataset variability of each one. This approach assumed that the samples are connected through the drainage network that feeds each of the reservoirs. Thus, the pair of samples that showed the greatest difference between TDS values (greatest variability) were used for each reservoir. Based on the local geology, halite, calcite, dolomite, gypsum, K-feldspar and biotite were applied as the mineral phases, also considering $\mathrm{CO}_{2}$ availability and dissolution, precipitation and ion exchange processes. Halite and gypsum were included as $\mathrm{Cl}^{-}$and $\mathrm{SO}_{4}^{2-}$, sources associated with marine aerosol (Guler \& Thyne, 2004). Plagioclase participation was also tested, but was not considered thereafter since, as observed by Morán-Ramírez et al. (2016), this only led to an increase in the number of models, with no an important contribution to the modeling results. The models most consistent with the information obtained through the correlation and ionic ratios analyzed were selected. Knowledge concerning the saturation index (SI) is important to predict the dissolution or precipitation processes between minerals and water. The modeling also allows for SI calculations using only the water chemical composition results, without the need for solid phase sampling and mineralogical analyses (Ahmed et al., 2013; Barzegar et al., 2018). Concerning a specific mineral phase, an SI <- 0.05 indicates a subsaturation state (with a tendency to dissolve), while an $\mathrm{SI}>0.05$ corresponds to supersaturation (with a tendency to precipitate) and an SI between - 0.05 and +0.05 denotes an equilibrium state, i.e., saturation conditions (United States Geological Survey, 2013).

Table 4 displays the SI values, generated by the PHREEQC modeling concerning the main minerals, calcite, dolomite, gypsum and halite. Halite and gypsum presented SI <- 0.05 for the three reservoirs, indicating a subsaturation state in relation to these minerals, i.e., the sea salt always remained dissolved in the samples used in the modeling. The carbonated minerals calcite and dolomite varied between subsaturation and supersaturation at the Jacarecica I and Marcela reservoirs, with a dissolution trend observed for the 2013 samples and a precipitation trend for the 2018 samples. Regarding the Ribeirópolis samples, calcite and 
Table 4. Saturation indices calculated for the main surface water minerals for the Jacarecica I, Macela and Ribeirópolis reservoirs.

\begin{tabular}{|c|c|c|c|c|c|c|}
\hline \multirow{2}{*}{ Mineral phases } & \multicolumn{2}{|c|}{ SI Jacarecica I } & \multicolumn{2}{|c|}{ SI Macela } & \multicolumn{2}{|c|}{ SI Ribeirópolis } \\
\hline & Nov.13 & Nov.18 & Jun.13 & Ago.18 & Jun.14 & Mai.18 \\
\hline Calcite & -1.13 & 0.49 & -0.34 & 0.79 & 0.67 & 0.75 \\
\hline Dolomite & -1.54 & 1.45 & -0.35 & 1.73 & 1.58 & 1.85 \\
\hline Gypsum & -4.76 & -3.98 & -2.49 & -2.40 & -2.57 & -2.53 \\
\hline Halite & -7.35 & -6.81 & -6.34 & -6.30 & -6.03 & -5.79 \\
\hline
\end{tabular}

Table 5. Mass transfer results generated in the reverse geochemical modeling. The different models represent the plausible alternatives for the geochemical processes occurring between the initial and final samples. Positive values indicate dissolution and negative values, precipitation.

\begin{tabular}{|c|c|c|c|c|c|c|c|c|}
\hline \multirow{3}{*}{$\begin{array}{l}\text { Mineral } \\
\text { phases }\end{array}$} & \multirow{2}{*}{\multicolumn{2}{|c|}{$\begin{array}{c}\text { Jacarecica I } \\
\text { Model }\left(\mathrm{mol} \mathrm{L}^{-1}\right)\end{array}$}} & \multicolumn{3}{|c|}{ Macela } & \multicolumn{3}{|c|}{ Ribeirópolis } \\
\hline & & & \multicolumn{3}{|c|}{ Model $\left(\mathrm{mol} \mathrm{L}^{-1}\right)$} & \multicolumn{3}{|c|}{ Model (mol L-1) } \\
\hline & A & B & $\mathbf{A}$ & B & $\mathrm{C}$ & $\mathbf{A}$ & B & $\mathrm{C}$ \\
\hline Calcite & $+1.9 \times 10^{-4}$ & $+6.8 \times 10^{1}$ & $+7.2 \times 10^{1}$ & $+4.6 \times 10^{-2}$ & $+8.4 \times 10^{-4}$ & - & $-1.7 \times 10^{2}$ & $+8.2 \times 10^{1}$ \\
\hline Dolomite & $+1.4 \times 10^{-4}$ & $-6.8 \times 10^{1}$ & $-7.2 \times 10^{1}$ & - & $-3.8 \times 10^{-4}$ & $+4.4 \times 10^{1}$ & - & $-8.2 \times 10^{1}$ \\
\hline Gypsum & $-1.4 \times 10^{-6}$ & $+6.1 \times 10^{-6}$ & $+1.8 \times 10^{-4}$ & $+5.0 \times 10^{-4}$ & $+5.0 \times 10^{-5}$ & $-5.6 \times 10^{-5}$ & $+1.9 \times 10^{-4}$ & $+1.1 \times 10^{-4}$ \\
\hline Halite & $+1.5 \times 10^{-3}$ & $+1.9 \times 10^{-3}$ & $+1.8 \times 10^{-3}$ & $+3.2 \times 10^{-4}$ & $+3.2 \times 10^{-4}$ & - & $+1.2 \times 10^{-2}$ & $+8.0 \times 10^{-3}$ \\
\hline Biotite & $+1.7 \times 10^{-4}$ & $+2.3 \times 10^{1}$ & $+2.4 \times 10^{-1}$ & $-1.5 \times 10^{-5}$ & $-1.7 \times 10^{-5}$ & $-3.0 \times 10^{1}$ & $+5.6 \times 10^{1}$ & $+2.7 \times 10^{1}$ \\
\hline K-feldspar & $+1.4 \times 10^{-5}$ & $-2.3 \times 10^{1}$ & $+2.4 \times 10^{-1}$ & $-2.1 \times 10^{-4}$ & $-3.3 \times 10^{-4}$ & $+3.0 \times 10^{1}$ & $-5.6 \times 10^{1}$ & $+2.7 \times 10^{1}$ \\
\hline $\mathrm{CaX}_{2}$ & $+1.4 \times 10^{-4}$ & - & $-4.2 \times 10^{-4}$ & $-3.4 \times 10^{-4}$ & $-3.4 \times 10^{-4}$ & $-4.4 \times 10^{+1}$ & $+1.7 \times 10^{2}$ & $+2.0 \times 10^{-3}$ \\
\hline $\mathrm{NaX}$ & $-2.8 \times 10^{-4}$ & - & $+8.3 \times 10^{-4}$ & $+6.8 \times 10^{-4}$ & $+6.8 \times 10^{-4}$ & $-2.7 \times 10^{-3}$ & $-4.7 \times 10^{-3}$ & $-4.0 \times 10^{-3}$ \\
\hline
\end{tabular}

dolomite were always in the supersaturation state. Many studies have cited these subsaturation and supersaturation variations for calcite and dolomite and have highlighted that low atmospheric precipitation and high evaporation, especially in arid and semi-arid regions, are the main factors that contribute to the precipitation of these minerals (Morán-Ramírez et al., 2016; Wang et al., 2017; Liu et al., 2020c).

The calculated concentrations of $\mathrm{CO}_{2}(\mathrm{~g})$ in the water samples from the reservoirs were $1.4 \times 10^{-5} \mathrm{~mol} \mathrm{~L}^{-1}$ (nov.13) and $1.6 \times 10^{-5} \mathrm{~mol} \mathrm{~L}^{-1}$ (nov.18) for Jacarecica I; $3.1 \times 10^{-5} \mathrm{~mol} \mathrm{~L}^{-1}$ (aug.18) and $2.7 \times 10^{-5} \mathrm{~mol} \mathrm{~L}^{-1}$ (jun.13) for Macela and $4.8 \times 10^{-5} \mathrm{~mol} \mathrm{~L}^{-1}$ (jun.14) and $3.3 \times 10^{-5} \mathrm{~mol} \mathrm{~L}^{-1}$ (may.18) for Ribeirópolis.

Table 5 presents the mass transfer values obtained as a result of the inverse modeling, where positive values indicate mass entry into the water (mineral dissolution) and negative values represent mass output from the water (mineral precipitation). In order to facilitate the understanding and discussion of the inverse modeling results, the variations of $\mathrm{Na}^{+}, \mathrm{K}^{+}, \mathrm{Ca}^{2+}, \mathrm{Mg}^{2+}$, $\mathrm{SO}_{4}^{2-}, \mathrm{Cl}^{-}, \mathrm{HCO}_{3}^{-}, \mathrm{pH}$ and water temperature $(\mathrm{T})$ values between the samples with the lowest and highest TDS concentration are presented in Figure 5.

Regarding Jacarecica I (Figure 5a), the geochemical variations between the sample nov.13 (TDS $=123 \mathrm{mg} \mathrm{L}^{-1}$ ) and the sample nov.18 (STD $\left.=332 \mathrm{mg} \mathrm{L}^{-1}\right)$ resulted in an increase in $\mathrm{Na}^{+}, \mathrm{K}^{+}$, $\mathrm{Ca}^{2+}, \mathrm{Mg}^{2+}, \mathrm{Cl}^{-}$and $\mathrm{HCO}_{3}^{-}$, concentrations, and practically no variation in $\mathrm{SO}_{4}^{2-}$ concentrations. The PHREEQC generated two models (Table 5) with the attempt to explain the evolution of the chemical composition between both samples. In both models, the transfer of similar moles from halite represents sea salt dissolution, thus responsible for increased $\mathrm{Cl}^{-}$and $\mathrm{Na}^{+}$concentrations. Ion exchange was very low in model $\mathrm{A}$ and nonexistent in model $\mathrm{B}$, with, therefore, no effect in relation to variations in $\mathrm{Na}^{+}$and $\mathrm{Ca}^{2+}$ concentrations. Calcite dissolution $\left(68 \mathrm{~mol} \mathrm{~L}^{-1}\right)$ and biotite
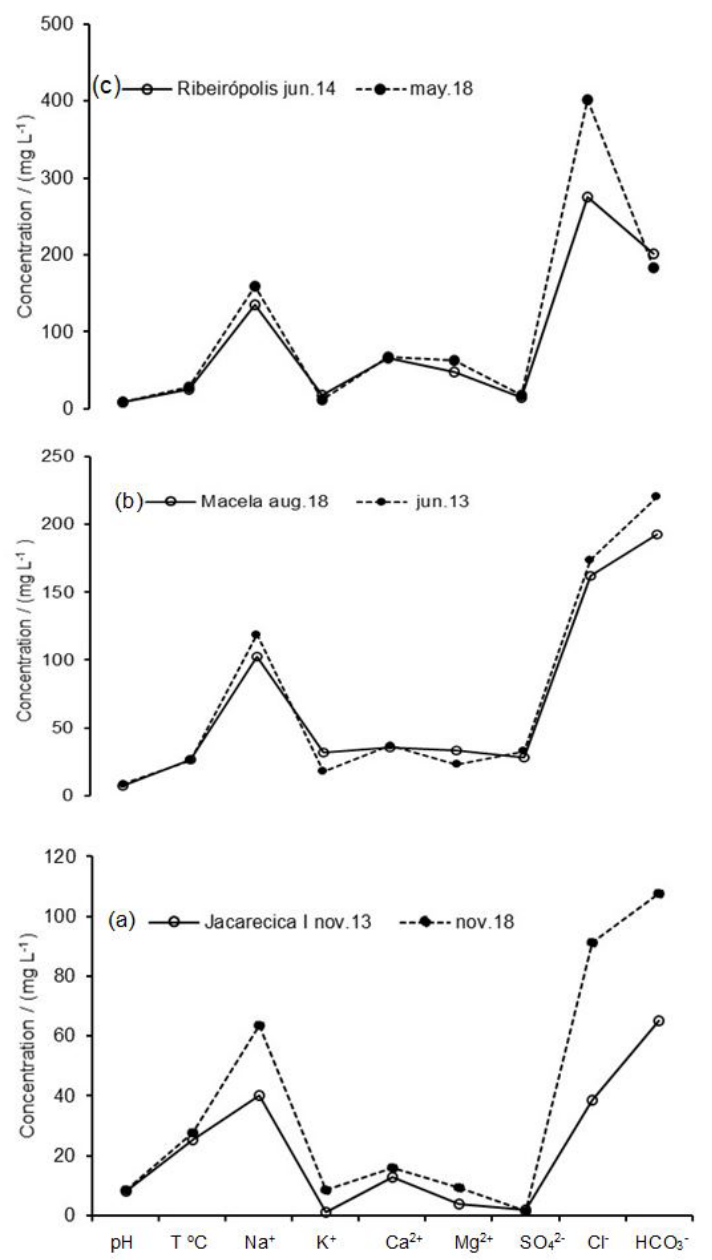

Figure 5. Ion concentration variations between between the smallest (solid line) and largest (dotted line) TDS sample for (a) Jacareica I Reservoir; (b) Macela Reservoir; (c) Ribeirópolis Reservoir. 
weathering $\left(23 \mathrm{~mol} \mathrm{~L}^{-1}\right)$ were the main source of increased $\mathrm{Ca}^{2+}$, $\mathrm{Mg}^{2+}, \mathrm{K}^{+}$and $\mathrm{HCO}_{3}{ }_{3}^{-}$concentrations, since dolomite and $\mathrm{K}$-feldspar showed very low dissolution $\left(\leq 1.4 \times 10^{-4} \mathrm{~mol} \mathrm{~L}^{-1}\right)$.

The geochemical variations between the Aug.18 $\left(\mathrm{STD}=664 \mathrm{mg} \mathrm{L}^{-1}\right)$ and Jun.13 (STD $\left.=1380 \mathrm{mg} \mathrm{L}^{-1}\right)$ samples from the Macela reservoir (Figure $5 \mathrm{~b}$ ) led to a greater increase in $\mathrm{Na}^{+}, \mathrm{Cl}^{-}$and $\mathrm{HCO}_{3}$, a small increase in $\mathrm{Ca}^{2+}$ and $\mathrm{SO}_{4}^{2-}$ and decrease in $\mathrm{K}^{+}$and $\mathrm{Mg}^{2+}$ content. The PHREEQC generated three models that together provided information to explain the variations observed for the Macela reservoir (Table 5). Halite dissolved in models $\mathrm{A}, \mathrm{B}$ and $\mathrm{C}$, indicating that the increase in $\mathrm{Na}^{+}$ and $\mathrm{Cl}$ is a result of sea salt dissolution. Ion exchanges between $\mathrm{Na}^{+}$and $\mathrm{Ca}^{2+}$ were identified in the three models. During the ion exchange process, $\mathrm{NaX}\left(8.3 \times 10^{-4} \mathrm{~mol} \mathrm{~L}^{-1}\right)$ was dissolved, while $\mathrm{CaX}_{2}\left(-4.2 \times 10^{-4} \mathrm{~mol} \mathrm{~L}^{-1}\right)$ was removed, leading to an increase in $\mathrm{Na}^{+}$in relation to $\mathrm{Cl}^{-}$. In models $\mathrm{A}$ and $\mathrm{C}$, calcite dissolves and dolomite precipitates, suggesting that the dissolution of the calcite induces the precipitation of the dolomite. Therefore, calcite is possibly the main source for the increase in $\mathrm{Ca}^{2+}$ and $\mathrm{HCO}_{3}{ }^{-}$concentrations. The lower variation of $\mathrm{Ca}^{2+}$ compared to $\mathrm{HCO}_{3}^{-}$is due to its removal by the ion exchange process. The precipitation of dolomite in models $\mathrm{A}$ and $\mathrm{B}$ justifies the decrease of $\mathrm{Mg}^{2+}$ concentrations.

For the Ribeirópolis reservoir (Figure 5c), the geochemical variations between the samples collected in Jun.14 (TDS $=973 \mathrm{mg} \mathrm{L}^{-1}$ ) and May.18 (TDS $=1150 \mathrm{mg} \mathrm{L}^{-1}$ ) resulted in a more pronounced increase in $\mathrm{Na}^{+}, \mathrm{Mg}^{2+}$ and $\mathrm{Cl}^{-}$concentrations and a decrease in $\mathrm{HCO}_{3}$ - concentrations, while $\mathrm{K}^{+}, \mathrm{Ca}^{2+}$ and $\mathrm{SO}_{4}^{2-}$ hardly changed. The PHREEQC modeling also gave rise to three models (Table 5). The high dissolution $\left(1.2 \times 10^{-2} \mathrm{~mol} \mathrm{~L}^{-1}\right)$ of sea salt (halite) led to a high increase in $\mathrm{Cl}^{-} \mathrm{Na}^{+}$did not increase in the same proportion due to ion exchanges with $\mathrm{Ca}^{2+}$, which induced considerable $\mathrm{NaX}$ removal $\left(-2.7 \times 10^{-3}\right.$ to $\left.-4.7 \times 10^{-3} \mathrm{~mol} \mathrm{~L}^{-1}\right)$ and $\mathrm{CaX}_{2}$ dissolution $\left(2.0 \times 10^{-3}\right.$ to $\left.1.7 \times 10^{2} \mathrm{~mol} \mathrm{~L}^{-1}\right)$. Calcite precipitation in model $\mathrm{B}$, with a mass transfer $\left(-1.7 \times 10^{2} \mathrm{~mol} \mathrm{~L}^{-1}\right)$ equal to $\mathrm{CaX}_{2}$ dissolution $\left(1.7 \times 10^{2} \mathrm{~mol} \mathrm{~L}^{-1}\right)$ explains the small variation in $\mathrm{Ca}^{2+}$ concentrations and the decrease in $\mathrm{HCO}_{3}{ }_{3}$ concentrations. Dolomite was dissolved in model $\mathrm{A}$ and precipitated in model $\mathrm{C}$, with precipitation rates greater than dissolution, while biotite was dissolved in B and C. This suggests that biotite weathering must be, mainly, responsible for the increases in $\mathrm{Mg}^{2+}$ concentrations.

For the Macela and Ribeirópolis reservoirs, the quantities of mol L ${ }^{-1}$ transferred by biotite and $\mathrm{K}$-feldspar point to an increase in the concentration of $\mathrm{K}^{+}$. However, what was observed in the samples (Figures 5b and 5c) was a low variation between the samples from the Ribeiropolis reservoir and a decrease between the samples from the Macela reservoir. It is likely that this deviation in modeling is due to the contribution of anthropogenic input and this is not considered in geochemical modeling. Potassium salts are widely used in industry and in fertilisers for agriculture and enter freshwaters with industrial discharges and runoff from agricultural land (Chapman, 1996).

$\mathrm{SO}_{4}^{2-}$, represented by gypsum, displayed a small increase in concentrations between the samples used in modeling for the Macela and Ribeirópolis reservoirs. The greatest variation was observed at the Macela reservoir, as molar transfers were slightly higher when compared to those in Ribeirópolis.
In general, the results of the inverse modeling corroborate with the observations of the correlation and ionic ratios analyses, which indicate sea salt dissolution, silicate weathering and, to a lesser extent, carbonate dissolution, as the main geochemical processes responsible for the water chemistry characteristics of the three reservoirs, including confirming the importance of ion exchange for the Macela and Ribeirópolis reservoirs.

This study, therefore, suggests that the increasing salinization process (increases in TDS) of the investigated reservoirs is mainly controlled by mineral weathering, including sea salt and carbonate dissolution, and may also undergo the influence of local high evaporation rates and of anthropogenic contributions. The Gibbs diagram (Figure 3), however, confirmed that water-rock interactions (weathering) comprise the dominant mechanism, intensifying with reservoir age. Therefore, concerning samples from the older reservoirs (Marcela and Ribeirópolis) were positioned close to the line that separates weathering and evaporation processes. According to Santos et al. (2000) reservoir salinization is a recurrent problem in Northeastern Brazil, especially in the semi-arid region, and has increased with reservoir age or hydraulic retention time. These authors also suggest the renewal of accumulated water by controlling discharge flows and a more adequate management of irrigation water as possible strategies to decrease the speed of increasing salinization rates.

\section{CONCLUSIONS}

Correlation analysis, ionic ratios and geochemical modeling were used to characterize the geochemical processes that control the chemical water composition at the Jacarecia I, Macela and Ribeirópolis reservoirs, located in the state of Sergipe, Northeastern Brazil.

A PCA indicated that the waters of the three reservoirs exhibit different chemical compositions. The samples from the Jacarecica I reservoir are distinguished from the others by lower ionic concentrations and lower TDS values, while samples from the Ribeirópolis reservoir contained higher TDS, $\mathrm{Na}^{+}, \mathrm{Ca}^{2+}, \mathrm{Mg}^{2+}$ and $\mathrm{Cl}^{-}$concentrations and lower $\mathrm{K}^{+}, \mathrm{HCO}_{3}^{-}$and $\mathrm{SO}_{4}^{2-}$ concentrations compared to the Macela reservoir.

The combination of the Gibbs diagram, correlation analysis, ion ratios and inverse geochemical modeling allowed for the successful identifications of the main geochemical processes responsible for the chemical water characteristics of three reservoirs, namely sea salt dissolution, silicate weathering and, to a lesser extent, carbonate dissolution, with an important contribution from the ion exchange process to the Macela and Ribeirópolis reservoirs.

This study therefore suggests that the increasing salinization process (increases in TDS) of the investigated reservoirs is mainly controlled by mineral weathering, including sea salt and carbonate disolution, and may also undergo the influence of the high evaporation rates observed in the area, as well as anthropogenic contributions.

As a way of recovering the salinized reservoirs and reducing the speed of salinization, it is suggested to increase the renewal of the accumulated water by controlling the inflow rates, to remove 
or treat the sewage efluentes and wasterwater lauched into the reservoirs, and to make a better management of the irrigation water.

\section{ACKNOWLEDGEMENTS}

The authors would like to thank the National Council for Scientific and Technological Development (CNPq). This research is part of the "Hydrogeochemistry of the processes that control the salinization of the Sergipe reservoirs" project, approved in the Universal Call 2018 and supported by CNPq funding.

Thanks are also due to the Special Superintendence of Water Resources and the Environment (SERHMA/SEDURBS) and to the Sergipe Technological and Research Institute (ITPS), as this study used data generated in the "Monitoring of Surface Waters and Reservoirs in the State of Sergipe" project.

\section{REFERENCES}

Abdel Wahed, M. S. M., Mohamed, E. A., El-Sayed, M. I., M'nif, A., \& Sillanpää, M. (2014). Geochemical modeling of evaporation process in Lake Qarun, Egypt. Journal of African Earth Sciences, 97, 322-330. http://dx.doi.org/10.1016/j.jafrearsci.2014.05.008.

Abdel Wahed, M. S. M., Mohamed, E. A., El-Sayed, M. I., M’nif, A., \& Sillanpää, M. (2015). hydrogeochemical processes controlling the water chemistry of a closed saline lake located in Sahara Desert: lake Qarun, Egypt. Aquatic Geochemistry, 21(1), 31-57. http://dx.doi. org/10.1007/s10498-015-9253-3.

Ahmed, M. N., Abdel Samie, S. G., \& Badawy, H. A. (2013). Factors controlling mechanisms of groundwater salinization and hydrogeochemical processes in the Quaternary aquifer of the Eastern Nile Delta, Egypt. Environmental Earth Sciences, 68(2), 369-394. http:/ /dx.doi.org/10.1007/s12665-012-1744-6.

Alves, J. P. H., Fonseca, L. C., Chielle, R. S. A., \& Macedo, L. C. B. (2018). Monitoring water quality of the Sergipe River basin: an evaluation using multivariate data analysis. Revista Brasileira de Recursos Hídricos, 23(0), e27. http://dx.doi.org/10.1590/23180331.231820170124.

American Public Health Association - APHA. (2012). Standard methods for the examination of water and wastewater (22nd ed.). Washington: APHA.

Barzegar, R., Asghari Moghaddam, A., Nazemi, A. H., \& Adamowski, J. (2018). Evidence for the occurrence of hydrogeochemical processes in the groundwater of Khoy plain, northwestern Iran, using ionic ratios and geochemical modeling. Environmental Earth Sciences, 77(16), 1-17. http://dx.doi.org/10.1007/s12665-018-7782-y.

Bomfim, L. F. C., Costa, V. G., \& Benvenuti, S. M. P. (2002a). Projeto cadastro da infra-estrutura hídrica do nordeste: Estado de Sergipe: diagnóstico do município de Itabaiana (46 p.). Aracaju: CPRM. Retrieved in 2021, January 25, from http://www.cprm.gov.br/publique/media/ hidrologia/mapas_publicacoes/cadastro_infraestrutura_sergipe/ Itabaiana.pdf
Bomfim, L. F. C., Costa, V. G., \& Benvenuti, S. M. P. (2002b). Projeto cadastro da infra-estrutura hidrica do Nordeste: Estado de Sergipe: diagnóstico do município de Ribeirópolis (25 p.). Aracaju: CPRM. Retrieved in 2021, January 25, from http:/ / www.cprm.gov.br/publique/media/ hidrologia/mapas_publicacoes/cadastro_infraestrutura_sergipe/ Ribeiropolis.pdf

Carpenter, S. R., Stanley, E. H., \& Vander Zanden, M. J. (2010). State of the world's freshwater ecosystems: physical, chemical, and biological changes. Annual Review of Environment and Resources, 36(1), 75-99. http://dx.doi.org/10.1146/annurev-environ-021810-094524.

Chapman, D. (1996). A guide to use of biota, sediments and water in environmental monitoring (2nd ed.). London: F \& FN Spon Ltd.

D'el-Rey Silva, L. J. H. (1995). Tectonic evolution of the Sergipano Belt, NE Brazil. Revista de Geociências, 25(4), 315-332.

Das, B. K., \& Kaur, P. (2001). Major ion chemistry of Renuka lake and weathering processes, Sirmaur disrict, Himachal Pradesh, India. Journal of Environmental Geology, 40(7), 908-917. http://dx.doi. org/10.1007/s002540100268.

Delgado, C., Pacheco, J., Cabrera, A., Batllori, E., Orellana, R., \& Bautista, F. (2010). Quality of groundwater for irrigation in tropical karst environment: the case of Yucatán, Mexico. Agricultural Water Management, 97(10), 1423-1433. http://dx.doi.org/10.1016/j. agwat.2010.04.006.

Drever, J. I. (1982). The geochemistry of natural waters: surface and groundwater environments (3rd ed.). New Jersey: Prentice Hall.

El Alfy, M., Lashin, A., Abdalla, F., \& Al-Bassam, A. (2017). Assessing the hydrogeochemical processes affecting groundwater pollution in arid areas using an integration of geochemical equilibrium and multivariate statistical techniques. Environmental Pollution, 229, 760-770. PMid:28624130. http://dx.doi.org/10.1016/j. envpol.2017.05.052.

El Yaouti, F., El Mandour, A., Khattach, D., Benavente, J., \& Kaufmann, O. (2009). Salinization processes in the unconfined aquifer of Bou-Areg (NE Morocco): a geostatistical, geochemical, and tomographic study. Applied Geochemistry, 24(1), 6-31. http:/ / dx.doi.org/10.1016/j.apgeochem.2008.10.005.

Elsdon, T. S., De Bruin, M., Diepen, N. J., \& Gillanders, B. M. (2009). Extensive drought negates human influence on nutrients and water quality in estuaries. The Science of the Total Environment, 407(8), 3033-3043. PMid:19215967. http://dx.doi.org/10.1016/j. scitotenv.2009.01.012.

Empresa Brasileira de Pesquisa Agropecuária - EMBRAPA. (2021). Arvore do conhecimento: bioma Caatinga. Retrieved in 2021, January 22, from https:/ / www.agencia.cnptia.embrapa.br/gestor/bioma_ caatinga/arvore/CONT000g5twggzh02wx5ok01edq5s189t6ux.html

Farid, I., Zouari, K., Rigane, A., \& Beji, R. (2015). Origin of the groundwater salinity and geochemical processes in detritaland 
carbonate aquifers: case of Chougafiya basin (Central Tunisia). Journal of Hydrology, 530, 508-532. http://dx.doi.org/10.1016/j. jhydrol.2015.10.009.

Fontes, A. S., Zucchi, M. R., Medeiros, Y. D. P., \& Azevedo, A. E. G. (2015). Avaliação dos fatores intervenientes no processo de salinização em reservatórios superficiais do semiárido brasileiro. Revista Brasileira de Recursos Hídricos, 20(3), 708-721. http:/ /dx.doi. org/10.21168/rbrh.v20n3.p708-721.

Gaillardet, J., Dupré, B., Louvat, P., \& Allègre, C. J. (1999). Global silicate weathering and $\mathrm{CO} 2$ consumption rates deduced from the chemistry of large rivers. Chemical Geology, 159(1-4), 3-30. http:/ / dx.doi.org/10.1016/S0009-2541(99)00031-5.

Garcia, H. L., Silva, V. L., Marques, L. P., Garcia, C. A. B., Alves, J. P. H., Silva, M. G., \& Carvalho, F. O. (2012). Nível trófico do reservatório de Jacarecica I - Sergipe - Brasil. Scientia Plena, 8, 079905. Retrieved in 2020, December 11, from https://www. scientiaplena.org.br/sp/article/view/1025

Garrels, R. M. \& Mackenzie, F. T. (1967). Origin of the chemical compositions of some springs and lakes. In W. Stumm (Ed.), Equilibrium concepts in natural waters systems (Advanced in Chemistry Series, No. 67, pp. 222-242). Washington: American Chemical Society. http://dx.doi.org/10.1021/ba-1967-0067.ch010.

Gibbs, R. J. (1970). Mechanisms controlling World Water Chemistry. Science, 170(3962), 1088-1090. PMid:17777828. http://dx.doi. org/10.1126/science.170.3962.1088.

Guler, C., \& Thyne, G. D. (2004). Hydrologic and geologic factors controlling surface and groundwater chemistry in Indian Wells-Owens Valley area, southeastern California, USA. Journal of Hydrology, 285(1-4), 177-198. http://dx.doi.org/10.1016/j. jhydrol.2003.08.019.

Guo, J., Zhou, X., Wang, L., Zhang, Y., Shen, X., Zhou, H., Ye, S., \& Fang, B. (2018). Hydrogeochemical characteristics and sources of salinity of the springs near Wenquanzhen in the eastern Sichuan Basin, China. Hydrogeology Journal, 26(4), 1137-1151. http:/ / dx.doi. org/10.1007/s10040-017-1692-z.

Hammer, O., Harper, D. A. T., \& Ryan, P. D. (2001). Paleontological statistic. Oslo: University of Oslo. Retrieved in 2018, January 10, from http://folk.uio.no/ohammer/past

Han, D. M., Song, X. F., Currell, M. J., Yang, J. L., \& Xiao, G. Q. (2014). Chemical and isotopic constraints on evolution of groundwater salinization in the coastal plain aquifer of Laizhou Bay, China. Journal of Hydrology, 508, 12-27. http://dx.doi.org/10.1016/j. jhydrol.2013.10.040.

Jia, H., Qian, H., Zheng, L., Feng, W., Wang, H., \& Gao, Y. (2020). Alterations to groundwater chemistry due to modern water transfer for irrigation over decades. The Science of the Total Environment, 717, 137170. PMid:32062271. http://dx.doi.org/10.1016/j. scitotenv.2020.137170.
Jiang, L., Yao, Z., Liu, Z., Wang, R., \& Wu, S. (2015). Hydrochemistry and its controlling factors of rivers in the source region of the Yangtze River on the Tibetan Plateau. Journal of Geochemical Exploration, 155, 76-83. http://dx.doi.org/10.1016/j.gexplo.2015.04.009.

Johansson, O., Aimbetov, I., \& Jarsjö, J. (2009). Variation of groundwater salinity in the partially irrigated Amudarya River delta, Uzbekistan. Journal of Marine Systems, 76(3), 287-295. http:/ / dx.doi.org/10.1016/j.jmarsys.2008.03.017.

Karroum, M., Elgettafi, M., Elmandour, A., Wilske, C., Himi, M., \& Casas, A. (2017). Geochemical processes controlling groundwater quality under semi arid environment: a case study in central Morocco. The Science of the Total Environment, 609, 1140-1151. PMid:28787788. http://dx.doi.org/10.1016/j.scitotenv.2017.07.199.

Khalil, B., \& Ouarda, T. B. M. J. (2009). Statistical approaches used to assess and redesign surface water-quality monitoring networks. Journal of Environmental Monitoring, 11(11), 1915-1929. PMid:19890548. http://dx.doi.org/10.1039/b909521g.

Kim, K. (2003). Long-term disturbance of groundwater chemistry following well installation. Ground Water, 41(6), 780-789. PMid:14649861. http://dx.doi.org/10.1111/j.1745-6584.2003.tb02419.x.

Koh, D.-C., Ko, K.-S., Kim, Y., Lee, S.-G., \& Chang, H.-W. (2007). Effect of agricultural land use on the chemistry of groundwater from basaltic aquifers, Jeju Island, South Korea. Hydrogeology Journal, 15(4), 727-743. http://dx.doi.org/10.1007/s10040-006-0142-0.

Kumarasamy, P., Arthur James, R., Dahms, H., Byeon, C., \& Ramesh, R. (2014). Multivariate water quality assessment from the Tamiraparani river basin, Southern India. Environmental Earth Sciences, 71(5), 2441-2451. http://dx.doi.org/10.1007/s12665-013-2644-0.

Lerman, A. (2009). Saline lakes' response to global change. Aquatic Geochemistry, 15(1-2), 1-5. http://dx.doi.org/10.1007/ s10498-008-9058-8.

Lima, W. S., \& Garcia, C. A. B. (2008). Qualidade da água em Ribeirópolis - SE: o açude do Cajueiro e a Barragem do João Ferreira. Scientia Plena, 4, 122401. Retrieved in 2018, December 11, from https://scientiaplena.emnuvens.com.br/sp/article/view/650

Lin, C. Y., Abdullah, M. H., Praveena, S. M., Yahaya, A. H. B., \& Musta, B. (2012). Delineation of temporal variability and governing factors influencing the spatial variability of shallow groundwater chemistry in a tropical sedimentary island. Journal of Hydrology, 432-433, 26-42. http://dx.doi.org/10.1016/j.jhydrol.2012.02.015.

Liu, F., Wang, S., Yeh, T. C. J., Zhen, P., Wang, L., \& Shi, L. (2020a). Using multivariate statistical techniques and geochemical modelling to identify factors controlling the evolution of groundwater chemistry in a typical transitional area between Taihang Mountains and North China Plain. Hydrological Processes, 34(8), 1888-1905. http://dx.doi.org/10.1002/hyp.13701. 
Liu, F., Zhao, Z., Yang, L., Ma, Y., Li, B., Gong, L., \& Liu, H. (2020b). Phreatic water quality assessment and associated hydrogeochemical processes in an irrigated region along the Upper Yellow River, Northwestern China. Water, 12(2), 463. http:// dx.doi.org/10.3390/w12020463.

Liu, F., Zhao, Z., Yang, L., Ma, Y., Xu, Y., Gong, L., \& Liu, H. (2020c). Geochemical characterization of shallow groundwater using multivariate statistical analysis and geochemical modeling in an irrigated region along the upper Yellow River, Northwestern China. Journal of Geochemical Exploration, 215, 106565. http:/ / dx.doi.org/10.1016/j.gexplo.2020.106565.

Liu, P., Hoth, N., Drebenstedt, C., Sun, Y., \& Xu, Z. (2017). Hydrogeochemical paths of multi-layer groundwater system in coal mining regions: using multivariate statistics and geochemical modeling approaches. The Science of the Total Environment, 601-602, 1-14. PMid:28551533. http://dx.doi.org/10.1016/j.scitotenv.2017.05.146.

Manno, E., Vassallo, M., Varrica, D., Dongarrà, G., \& Hauser, S. (2006). Hydrogeochemistry and Water Balance in the Coastal Wetland Area of "Biviere di Gela,". Sicily Italy. Water, Air, and Soil Pollution, 178(1-4), 179-193. http://dx.doi.org/10.1007/ s11270-006-9189-8.

Marandi, A., \& Shand, P. (2018). Groundwater chemistry and the Gibbs Diagram. Applied Geochemistry, 97, 209-212. http://dx.doi. org/10.1016/j.apgeochem.2018.07.009.

Meireles, A. C. M., Frischkorn, H., \& Andrade, E. M. (2007). Sazonalidade da qualidade das águas do açude Edson Queiroz, bacia do Acaraú, no Semiárido cearense. Ciência Agronômica, 38(1), 25-31. Retrieved in 2018, December 11, from http:/ / ccarevista. ufc.br/seer/index.php/ccarevista/article/view/145

Merchán, D., Auqué, L. F., Acero, P., Gimeno, M. J., \& Causapé, J. (2015). Geochemical processes controlling water salinization in an irrigated basin in Spain: identification of natural and anthropogenic influence. The Science of the Total Environment, 502, 330-343. PMid:25262295. http://dx.doi.org/10.1016/j. scitotenv.2014.09.041.

Morán-Ramírez, J., Ledesma-Ruiz, R., Mahlknecht, J., \& Ramos-Leal, J. A. (2016). Rockewater interactions and pollution processes in the volcanic aquifer system of Guadalajara, Mexico, using inverse geochemical modeling. Applied Geochemistry, 68, 79-94. http:// dx.doi.org/10.1016/j.apgeochem.2016.03.008.

Mosaad, S., El Abd, E. S., \& Kehew, A. E. (2019). Integration of geochemical data to assess the groundwater quality in a carbonate aquifer in the southeast of Beni-Suef city, Egypt. Journal of African Earth Sciences, 158, 103558. http://dx.doi.org/10.1016/j. jafrearsci.2019.103558.

Nielsen, D. L., Brock, M. A., Rees, G. N., \& Baldwin, D. S. (2003). Effects of increasing salinity on fresh Water ecosystems in Australia. Australian Journal of Botany, 51(6), 655-665. http:// dx.doi.org/10.1071/BT02115.
Palácio, H. A. Q., Araújo Neto, J. R., Meireles, A. C. M., Andrade, E. M., Santos, J. C. N., \& Chaves, L. C. G. (2011). Similaridade e fatores determinantes na salinidade das águas superficiais do Ceará, por técnicas multivariadas. Revista Brasileira de Engenharia Agricola e Ambiental, 15(4), 395-402. http://dx.doi.org/10.1590/ S1415-43662011000400011.

Peck, A. J., \& Hatton, T. (2003). Salinity and the discharge of salts from catchments in Australia. Journal of Hydrology, 272(1-4), 191-202. http://dx.doi.org/10.1016/S0022-1694(02)00264-0.

Santos, I. S., Garcia, C. A., Passos, E. A., \& Alves, J. P. H. (2013). Distributions of Trace Metals in Sediment Cores from a Hypertrophic Reservoir in Northeast Brazil. Journal of the Brazilian Chemical Society, 24(2), 246-255. http://dx.doi.org/10.5935/0103-5053.20130032.

Santos, J. S., Oliveira, E., \& Massaro, S. (2000). Avaliação da salinização de açudes no semiárido brasileiro por ICP-AES. Quimica Nova, 23(4), 453-456. http:/ /dx.doi.org/10.1590/S010040422000000400004.

Santos, R. A., Martins, A. A. M., Neves, J. P., \& Leal, R. A. (2001). Programa Levantamentos Geológicos Básicos do Brasil-PLGB: geologia e recursos minerais do Estado de Sergipe (156 p.). Brasília: CPRM/ DIEDIG/DEPAT, CODISE. Retrieved in 2019, January 22, from http://rigeo.cprm.gov.br/jspui/bitstream/doc/19439/1/ proj_sergipe_relatorio.pdf

Sena, I. M. N., Monteiro, A. S. C., \& Alves, J. P. H. (2020). Variações na qualidade da água e no estado trófico do Reservatório Macela no período de 2004 a 2014. In I. F. Sousa, A. S. C. Monteiro \& N. R. F. Santana (Eds.), Olhar dos recursos e do meio ambiente do estado de Sergipe (1. ed., pp. 34-47). Belo Horizonte: Poisson. https://10.36229/978-85-7042-208-8.CAP.03.

Sharma, A., Singh, A. K., \& Kumar, K. (2012). Environmental geochemistry and quality assessment of surface and subsurface water of Mahi River basin, western India. Environmental Earth Sciences, 65(4), 1231-1250. http://dx.doi.org/10.1007/s12665-011-1371-7.

Shrestha, S., \& Kazama, F. (2007). Assessment of surface water quality using multivariate statistical techniques: a case study of the Fuji river basin, Japan. Environmental Modelling \& Software, 22(4), 464-475. http://dx.doi.org/10.1016/j.envsoft.2006.02.001.

Singh, A. K., Mondal, G. C., Kumar, S., Singh, T. B., Tewary, B. K., \& Sinha, A. (2008). Major ion chemistry, weathering processes and water quality assessment in upper catchment of Damodar River basin, India. Environmental Geology, 54(4), 745-758. http:/ / dx.doi.org/10.1007/s00254-007-0860-1.

Singh, A. K., Mondal, G. C., Singh, P. K., Singh, S., Singh, T. B., \& Tewary, B. K. (2005). Hydrochemistry of reservoirs of Damodar River basin, India: weathering processes and water quality assessment. Environmental Geology, 48(8), 1014-1028. http:/ / dx.doi.org/10.1007/s00254-005-1302-6. 
Singh, C. K., Kumar, A., Shashtri, S., Kumar, A., Kumar, P., \& Mallick, J. (2017). Multivariate statistical analysis and geochemical modeling for geochemical assessment of groundwater of Delhi, India. Journal of Geochemical Exploration, 175, 59-71. http://dx.doi. org/10.1016/j.gexplo.2017.01.001.

Singh, K. P., Malik, A., Mohan, D., \& Sinha, S. (2004). Multivariate statistical techniques for the evaluation of spatial and temporal variations in water quality of Gomti River (India): a case study. Water Research, 38(18), 3980-3992. PMid:15380988. http://dx.doi. org/10.1016/j.watres.2004.06.011.

Slama, F., \& Bouhlila, R. (2017). Multivariate statistical analysis and hydrogeochemical modelling of seawater-freshwater mixing along selected flow paths: case of Korba coastal aquifer Tunisia. Estuarine, Coastal and Shelf Science, 198, 636-647. http://dx.doi. org/10.1016/j.ecss.2016.10.005.

Souza Filho, F. D. A. D., \& Campos, J. N. B. (2002). Um método paramétrico de avaliação do potencial de salinização de reservatórios aplicado a regiões semiáridas. Revista Brasileira de Recursos Hídricos, 10(2), 5-14. https://dx.doi.org/10.21168/rbrh.v10n2.p5-14.

Subramani, T., Rajmohan, N., \& Elango, L. (2010). Groundwater geochemistry and identification of hydrogeochemical processes in a hard rock region, Southern India. Environmental Monitoring and Assessment, 162(1-4), 123-137. PMid:19247793. http://dx.doi. org/10.1007/s10661-009-0781-4.

Tweed, S., Grace, M., Leblanc, M., Cartwright, I., \& Smithyman, D. (2011). The individual response of saline lakes to a severe drought. The Science of the Total Environment, 409(19), 3919-3933. PMid:21752428. http://dx.doi.org/10.1016/j.scitotenv.2011.06.023.

United States Geological Survey - USGS. (2013) Description of input and examples for PHREEQC version 3: a computer program for speciation, batch-reaction, one-dimensional transport, and inverse geochemical calculations. In D. L. Parkhurst \& C. A. J. Appelo (Eds.) Techniques and methods 6-A43 (497 p.). Washington: U.S. Geological Survey. Retrieved in 2018, December 11, from http://pubs.usgs.gov/tm/06/a43

Wang, L., Dong, Y., Xu, Z., \& Qiao, X. (2017). Hydrochemical and isotopic characteristics of groundwater in the northeastern Tennger Desert, northern China. Hydrogeology Journal, 25(8), 23632375. http://dx.doi.org/10.1007/s10040-017-1620-2.

Xing, L., Guo, H., \& Zhan, Y. (2013). Groundwater hydrochemical characteristics and processes along flow paths in the North China
Plain. Journal of Asian Earth Sciences, 70-71, 250-264. http://dx.doi. org/10.1016/j.jseaes.2013.03.017.

Yan, B., Xiao, C., Liang, X., \& Wu, S. (2016). Hydrogeochemical tracing of mineral water in Jingyu County, Northeast China. Environmental Geochemistry and Health, 38(1), 291-307. PMid:26040975. http://dx.doi.org/10.1007/s10653-015-9719-7.

Zhang, Y., Xu, M., Li, X., Qi, J., Zhang, Q., Guo, J., Yu, L., \& Zhao, R. (2018). Hydrochemical characteristics and multivariate statistical analysis of natural water system: a case study in Kangding County, Southwestern China. Water, 10(1), 80. http://dx.doi. org/10.3390/w10010080.

Zhu, B., Wang, X., \& Rioual, P. (2017). Multivariate indications between environment and ground water recharge in a sedimentary drainage basin in northwestern China. Journal of Hydrology, 549, 92-113. http://dx.doi.org/10.1016/j.jhydrol.2017.03.058.

\section{Authors contributions}

José do Patrocinio Hora Alves: Contributed to date analysis, statistical processing of date, interpretation of results and writing of the article.

Maria Hortência Rodrigues Lima: Contributed to the realization of geochemical modeling and interpretation of hydrogeochemical processes.

Josefa Raimunda Dória: Contributed to the interpretation of hydrogeochemical processes using ionic ratios.

Igor Santos Silva: Contributed to the use of PHREEQC software to perform geochemical modeling.

Adnivia Santos Costa Monteiro: Contributed to the use of PHREEQC software to perform geochemical modeling and to the interpretation of hydrogeochemical processes using geochemical modeling.

Editor-in-Chief: Adilson Pinheiro

Associated Editor: Ibraim Fantin da Cruz 